\title{
Environmental Hf-Nd isotopic decoupling in World river clays
}

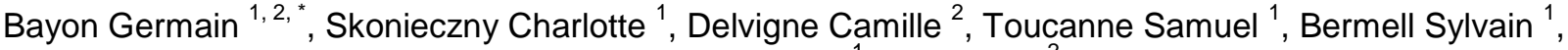 \\ Ponzevera Emmanuel ${ }^{1}$, André Luc ${ }^{2}$ \\ ${ }^{1}$ IFREMER, Unité de Recherche Géosciences Marines, F-29280 Plouzané, France \\ ${ }^{2}$ Royal Museum for Central Africa, Department of Earth Sciences, B-3080 Tervuren, Belgium \\ * Corresponding author : Germain Bayon, Tel.: +32 27695456 ; email addresses : gbayon@ifremer.fr ; \\ germain.bayon@africamuseum.be
}

\begin{abstract}
:
The hafnium and neodymium radiogenic isotope systems behave differently during Earth surface processes, causing a wide dispersion of $\mathrm{Hf}$ and $\mathrm{Nd}$ isotopic compositions in sediments and other sedimentary rocks. The decoupling between $\mathrm{Hf}$ and $\mathrm{Nd}$ isotopes in sediments is generally attributed to a combination of preferential sorting of zircon during sediment transport and incongruent weathering processes on continents. In this study, we analysed size-fractions of sediment samples collected near the mouth of 53 rivers worldwide to better understand the factors controlling the distribution of $\mathrm{Hf}$ and $\mathrm{Nd}$ isotopes in sediments. Our results for rivers draining old cratonic areas and volcanic provinces demonstrate that both granite and basalt weathering can lead to significant grain-size dependent $\mathrm{Hf}$ isotopic variability. While silt-size fractions mainly plot along the Terrestrial Array, World river clays are systematically shifted towards more radiogenic $\mathrm{Hf}$ isotopic compositions, defining together with published data a new Clay Array $(\varepsilon \mathrm{Hf}=0.78 \times \varepsilon \mathrm{Nd}+5.23 \varepsilon \mathrm{Hf}=0.78 \times \varepsilon \mathrm{Nd}+5.23)$. The $\mathrm{Hf}-\mathrm{Nd}$ isotope decoupling observed in volcanogenic sediments is best explained by selective alteration of Lu-rich mineral phases (e.g. olivine) and preferential enrichment of resistant unradiogenic minerals, such as spinel and ilmenite, in silt fractions. We also show that the extent to which World river clays deviate from the Clay Array $(\Delta \varepsilon \mathrm{Hf}$ clay $\Delta \varepsilon \mathrm{Hf}$ clay) is not linked to the presence of zircons. Instead, it correlates positively with weathering indices and climatic parameters (temperature, rainfall) of the corresponding drainage basins. Overall, these findings demonstrate that the distribution of $\mathrm{Hf}-\mathrm{Nd}$ isotopes in clay-size sediments is related to a large extent to weathering conditions on continents, although the precise mechanisms controlling this relationship remain unclear. We finally propose that the $\mathrm{Hf}-\mathrm{Nd}$ isotope pair proxy could be used in palaeoenvironmental studies to provide semi-quantitative information on past climates.
\end{abstract}

Keywords : hafnium isotopes, neodymium, rivers, clays, weathering, climate 


\section{1 - Introduction}

Weathering processes progressively lead, with time, to the disintegration of rocks on continents and development of soil sequences. Most silicate minerals are generally unstable at the Earth's surface, and typically weather to form clays (e.g. Velde, 1995). Upon formation in soils, clays incorporate a substantial fraction of the elements released during chemical weathering. Some of these elements are commonly referred to as immobile (e.g. Al, $\mathrm{Ti}, \mathrm{Zr}$ ), as opposed to other more mobile elements (e.g. $\mathrm{Na}, \mathrm{K}$ ), which often remain in solution and are exported away by freshwaters and/or bio-assimilated (e.g. Garrels and McKenzie, 1971). Due to their small grain-size, clays and other fine-grained erosion products such as silts are efficiently removed from soils during erosion, which also implies that they can be delivered to the ocean via rivers with presumably minimum transfer times compared to coarser sedimentary particles.

Over the past decades, studies of fine-grained sediments and river particulates have provided a wealth of information on both the composition of the exposed continental crust and chemical weathering processes (e.g. Taylor and McLennan, 1985; Gaillardet et al., 1999a). The abundance and isotopic composition of immobile elements are often used as tools for assessing the provenance of sedimentary rocks. Amongst these, rare earth elements (REE) and neodymium (Nd) isotopes have received particular attention over the years (e.g. Goldstein et al., 1984; McLennan, 1989). Detrital sediments are thought to retain the Nd isotopic composition of their source rocks during continental weathering, sedimentary and post-depositional processes (e.g. Goldstein et al., 1984). As a consequence, Nd isotopes are often used for tracing the geographical provenance of sediments (e.g. Goldstein and Hemming, 2003). In contrast, the degree of chemical weathering of soils and associated source rocks is generally evaluated using indices of the relative abundance of immobile versus mobile elements, such as the widely used chemical index of alteration (CIA; Nesbitt and Young, 1982). Radiogenic isotope systems other than Nd (e.g. Pb, Sr, Os) have also proven to be particularly useful for tracing weathering processes (e.g. Erel et al., 1994). Their application to sedimentary rocks is based on evidence that incongruent dissolution of silicate rocks during chemical weathering leads to products of erosion having distinctive radiogenic isotopic compositions. Recently, the emergence of non-traditional stable isotope geochemistry (e.g. $\mathrm{Li}, \mathrm{Si}, \mathrm{Mg}$ ) has also led to promising perspectives for further understanding the links between clay mineral formation and the surrounding bio- and hydro-spheres (e.g. Opfergelt et al., 2010; von Strandmann et al., 2012). 
In addition to the various proxies listed above, hafnium (Hf) isotopes also represent interesting tracers of silicate weathering, in particular when their measurement is combined with Nd isotopes. Despite behaving relatively similarly during magmatic processes (Vervoort et al., 1999), the Lu-Hf and Sm-Nd radiogenic isotopic systems are strongly decoupled by Earth surface processes (e.g. van de Flierdt et al., 2007). A substantial fraction of the Hf budget in rocks and sediments is indeed hosted in zircons, a mineral characterized by very unradiogenic isotopic compositions (i.e. low ${ }^{176} \mathrm{Hf} /{ }^{177} \mathrm{Hf}$ ratios or $\varepsilon_{\mathrm{Hf}}$ values). Zircons are highly resistant to weathering and preferentially sorted into coarse-grained fractions during sediment transport (Patchett et al., 1984). In addition to this 'zircon effect', silicate weathering also leads to preferential dissolution of Lu-rich mineral phases such as apatite and sphene, which releases radiogenic $\mathrm{Hf}$ (i.e. high ${ }^{176} \mathrm{Hf} /{ }^{177} \mathrm{Hf}$ ratios or $\varepsilon_{\mathrm{Hf}}$ values) to river waters and presumably to seawater (Bayon et al., 2006; Godfrey et al., 2007). The observed decoupling between $\mathrm{Hf}$ and $\mathrm{Nd}$ isotopes during Earth surface processes is clearly illustrated in the $\varepsilon_{\mathrm{Hf}}$ vs. $\varepsilon_{\mathrm{Nd}}$ diagram, where fine-grained sediments display a wide range of Hf-Nd isotopic compositions between the Terrestrial Array (Vervoort et al., 2011) and the Seawater Array (Albarède et al., 1998), which both refer to the broad correlations defined by most terrestrial rocks and seawater/marine precipitates, respectively (Fig. 1). Collectively, analyses of marine sediments (Vervoort et al., 1999; Pettke et al., 2002; Vlastelic et al., 2005; Prytulac et al., 2006; van de Flierdt et al., 2007; Bayon et al., 2009a; Carpentier et al., 2009; Vervoort et al., 2011; Carpentier et al., 2014), river particulates, bedloads and zircon grains (Bayon et al., 2006; Chen et al., 2011; Rickli et al., 2013; Garçon et al., 2013; Garçon et al., 2014; Garçon and Chauvel, 2014), loess deposits (Chen et al., 2013; Chauvel et al., 2014) and aeolian dusts (Lupker et al., 2010; Rickli et al., 2010; Aarons et al., 2013; Chen et al., 2013; Pourmand et al., 2014; Zhao et al., 2014) all indicate that coarse-grained (and/or zircon-rich) sediments typically fall along or below the Terrestrial Array, while clay-size (and/or zircon-poor) fractions generally display more radiogenic Hf signatures (Fig. 1). To a large extent, the observed decoupling can be explained by mineralogical sorting processes that occur during sediment transport (e.g. van de Flierdt et al., 2007; Aarons et al., 2013; Garçon et al., 2013). However, recent investigations of Late Quaternary sediments from the Congo fan area also led to the suggestion that the distribution of Hf-Nd isotopes in fine-grained sediments could be controlled instead by chemical weathering intensity on continents (Bayon et al., 2009a; Bayon et al., 2012). 
In view of the above consideration, the main aim of this study was to further evaluate the relative role of mineralogical versus weathering processes in explaining the observed large dispersion of $\mathrm{Hf}$ and $\mathrm{Nd}$ isotopic ratios in fine-grained sediments. To this purpose, we have analysed a large set of sediments deposited near the mouth of rivers worldwide, for which we report ${ }^{176} \mathrm{Hf} /{ }^{177} \mathrm{Hf}$ and ${ }^{143} \mathrm{Nd} /{ }^{144} \mathrm{Nd}$ ratios on both silt $(2-63 \mu \mathrm{m})$ and clay $(<2 \mu \mathrm{m})$ sizefractions. These results allow us to identify new key parameters (temperature, rainfall) that control the distribution of Hf-Nd isotopes in clay-size detrital fractions.

\section{2 - Samples and methods}

\subsection{River-borne sediments and corresponding basin characteristics}

The sediment samples analysed during the course of this study were collected near the mouth of rivers (Fig. 2). They correspond to either marine core-top (or sub-surface) or river bank sediments, both from major river systems and rivers draining basins with particular geological and climatic contexts (Table S1). For clarity, studied samples were organised into four groups (Table 1): 1) Major river systems with watersheds larger than 100,000 km² (e.g. Amazon, Congo, Mississippi, Nile); 2) Rivers draining sedimentary basins and/or various lithologies, but with drainage areas smaller than 100,000 $\mathrm{km}^{2}$ (e.g. Seine, Fly); 3) Rivers draining igneous/metamorphic terranes, such as the Proterozoic cratonic regions of Fennoscandia and Northern South America; 4) Rivers draining volcanic provinces (e.g. Kamtchatka peninsula, New Zealand, Reunion Island). Several minor rivers were sampled in North-West and Northern Ireland (Fig. 2C), draining a large variety of mono-lithological formations (i.e. Paleocene basaltic rocks, Paleozoic sedimentary formations, Proterozoic metamorphic rocks). These rivers are characterized by a similar climatic setting, and hence are ideal to investigate separately the role of lithology in controlling the Hf-Nd isotopic distribution in sediments. In addition, a total of seven sediment samples were collected along a 50-km transect along the flow path of the Loire River estuary, corresponding to various depositional environments. These latter samples were used to assess the analytical uncertainty associated with sediment sampling and preparation. The mean annual air temperatures (MAT) and precipitations (MAP) data for each river basin were derived from the literature (e.g. Pinet and Souriau, 1988) and the CLIMWAT climatic database managed by the Food and Agriculture Organization of the United Nations (FAO). 


\subsection{Chemical and analytical procedures}

Prior to chemical preparation, dry bulk samples were sieved through a $63 \mu \mathrm{m}$ mesh to collect the fine-grained fraction. Non-terrigenous sedimentary components (i.e. carbonates, Fe-Mn oxyhydroxides and organic components) were removed using a sequential leaching procedure (Bayon et al., 2002). Clay- $(<2 \mu \mathrm{m})$ and silt-size $(\sim 2-63 \mu \mathrm{m})$ fractions were separated from detrital residues by low-speed centrifugation (for details, see Bayon et al., 2015). On average, this separation led to the distribution of about $10 \%$ and $90 \mathrm{wt} \%$ of the bulk detrital material within the clay- and silt-size fractions, respectively, indicating that the studied $(<63 \mu \mathrm{m})$ river-borne sediments were dominated by silt-size $(2-63 \mu \mathrm{m})$ particles (Table S1). Separate size-fractions were digested by alkaline fusion to achieve quantitative dissolution of very resistant refractory mineral phases such as zircons (Bayon et al., 2009b). Hafnium and neodymium were separated by conventional ion chromatography (Chu et al., 2002; Bayon et al., 2012) and isotopic measurements were performed with a Neptune multicollector ICPMS (Thermo Scientific) at the Pôle Spectrométrie Océan (Brest, France). For Hf isotopes, mass bias corrections were made with the exponential law, using ${ }^{179} \mathrm{Hf} /{ }^{177} \mathrm{Hf}=$ 0.7325. Hf isotopic compositions were determined using sample-standard bracketing, by analysing JMC 475 standard solutions with matched concentrations every two samples. Mass-bias corrected values for ${ }^{176} \mathrm{Hf} /{ }^{177} \mathrm{Hf}$ were normalized to a JMC 475 value of 0.282163 (Blichert-Toft et al., 1997). Repeated analyses of JMC 475 during the course of this study gave ${ }^{176} \mathrm{Hf} /{ }^{177} \mathrm{Hf}$ of $0.282153 \pm 0.000006$ (2 SD, $\mathrm{n}=37 ; 200 \mathrm{ppb}$ solution), which corresponds to an external reproducibility of $\pm 0.2 \varepsilon$ (2 SD). Note that the uncertainty associated with sediment sampling and preparation was $\pm 0.3 \varepsilon$ ( $1 \mathrm{SD}$ ), as estimated from the analysis of the Loire River samples (Table 1). The epsilon Hf values $\left(\varepsilon_{\mathrm{Hf}}\right)$ were calculated using ${ }^{176} \mathrm{Hf} /{ }^{177} \mathrm{Hf}$ $=0.282785$ (Bouvier et al., 2008).

In addition to Hf isotopes, clay mineralogy, major/trace element abundances and $\mathrm{Nd}$ isotopic compositions were also determined on the same samples, and discussed in a companion paper, dealing with the application of rare earth elements (REE) and Nd isotopes for sediment provenance studies and for estimating the average composition of the eroded upper continental crust (Bayon et al., 2015). These data confirmed that river sediment did not generally exhibit grain-size dependent $\mathrm{Nd}$ isotopic variability, but also suggested that subtle decoupling could occur for Nd isotopes between clay- and silt-size fractions from large river 
basins (e.g. Nile, Fraser, Chao Phraya), caused by preferential weathering of volcanic and sedimentary rocks relative to more resistant lithologies. The chemical index of alteration (CIA) determined from major element compositions for the same suite of river clay-size fractions provides an estimate of the depletion of mobile ( $\mathrm{Ca}, \mathrm{Na}, \mathrm{K})$ versus immobile (Al) elements, and hence can be used as an indicator of the degree of feldspar weathering (see discussion in Bayon et al., 2015).

\section{3 - Results}

As mentioned above, the studied river-borne sediments exhibit negligible grain-size dependent Nd isotopic variability (Table 2; Bayon et al., 2015). The strong dominance of 2$63 \mu \mathrm{m}$ particles relative to the finer $<2 \mu \mathrm{m}$ detrital fractions in the studied sediment samples clearly indicates that the corresponding bulk sediment $\mathrm{Nd}$ and $\mathrm{Hf}$ budgets are to a large extent controlled by silt-size fractions (Table S1). In contrast to $\mathrm{Nd}$ isotopes, the $\mathrm{Hf}$ isotopic composition of silt-size fractions is systematically lower than values for corresponding clays (Table 2; Fig. 3). World river silts plot along (or near) the Terrestrial Array, with $\varepsilon_{\mathrm{Hf}}$ values ranging from $\sim-47$, for the case of sediments draining old cratonic areas, to +9 for mantlederived volcanogenic sediments (Fig. 3). In comparison, the dispersion of $\varepsilon_{\mathrm{Hf}}$ values in clays is smaller (between $\sim-22$ to +14 ). In the $\varepsilon_{\mathrm{Hf}}$ versus $\varepsilon_{\mathrm{Nd}}$ Scatter diagram, World river clays plot in the upper (radiogenic) part of the field of published data for fine-grained sediments, just below the Seawater Array (Fig. 3). An exception is the clay-size fraction from the Orinoco River (sample \#10 in Fig. 1 and Table 2). In addition to being anomalously unradiogenic compared to the other clay-size fractions analysed in this study ( $\varepsilon_{\mathrm{Hf}}=-17.0$; Fig. 3), the Orinoco sample is also characterised by a much higher $\mathrm{Zr}$ concentration (377 ppm) compared to other studied river clays. These observations clearly indicate the presence of zircons in this particular sample. Note that another clay sample (Kiiminkijoki \#43) also displays a relatively unradiogenic Hf signature $\left(\varepsilon_{\mathrm{Hf}}=-21.6\right.$; Fig. 3), but without exhibiting any particular high $\mathrm{Zr}$ concentration (137 ppm; Table S2), nor any particular heavy-REE enrichment that would indicate the presence of zircon (Bayon et al., 2015). Apart from these two exceptions, the observed distribution of Hf-Nd isotopes for World river clays agrees remarkably well with values reported recently for clay-size fractions of Chinese loess (Chen et al., 2013) and Chinese/Mongolian dusts (Zhao et al., 2014). Taken together with these two sets of recently published Hf-Nd isotopic values, our data for World river clays (excluding the Orinoco 
sample) define a new Clay Array, characterized by the following simple linear regression: $\varepsilon_{\mathrm{Hf}}$ $=0.78( \pm 0.04) \times \varepsilon_{\mathrm{Nd}}+5.23( \pm 0.46)$, and a coefficient of determination $\left(\mathrm{R}^{2}\right)$ of 0.74 .

\section{4- Discussion}

\subsection{The Hf-Nd isotopic variation in World river silts and the 'zircon effect'}

Except for one sample (Galets, Réunion Island), all the World river silts investigated during the course of this study exhibit much higher Zr concentrations (median 311 ppm) than corresponding clay-size fractions (median 135 ppm; Table S2). Most likely, this reflects preferential enrichment of zircon grains (or other Zr-rich minerals; see discussion below for samples from volcanic basins) in the coarse-grained sediments relative to finer sediment fractions (e.g. Patchett et al., 1984; Bayon et al., 2009a; Garçon et al., 2013; Aarons et al., 2013). In Fig. 4, we examine the relationship between $\mathrm{Zr}$ abundances and the vertical deviation of Hf isotopic compositions of silt-size fractions relative to the Terrestrial Array $\left(\Delta \varepsilon_{\mathrm{Hf}}\right.$ terrestrial). The samples characterized by negative $\Delta \varepsilon_{\mathrm{Hf}}$ terrestrial values (i.e. with measured $\varepsilon_{\mathrm{Hf}}$ plotting 'below' the Terrestrial Array) generally correspond to $\mathrm{Zr}$ concentrations higher than UCC value (193 ppm; Rudnick and Gao, 2013), and vice versa. As proposed earlier (Vervoort et al., 2011), this observation clearly suggests that sediment samples plotting below the Terrestrial Array correspond to coarse-grained material having preferentially accumulated zircon during sorting processes. Two silt-size samples (Congo \#2 and Niger \#5) display particularly high $\Delta \varepsilon_{\mathrm{Hf}}$ terrestrial values $(>+10)$, associated with low $\mathrm{Zr}$ concentrations (about 140 ppm; Fig. 4). These samples correspond to fine-grained marine sediments recovered from relatively deep continental margin settings, at about $1000 \mathrm{~m}$ water depth. In this context, the observed shift towards more radiogenic Hf composition (high $\Delta \varepsilon_{\mathrm{Hf}}$ terrestrial values) is best explained by zircon depletion that would have occurred during sediment transport between the continent and the depositional site. Taken together, these observations hence suggest that the observed dispersion of studied samples below and above the Terrestrial Array is mainly due to the 'zircon effect'. In other terms, without any particular zircon enrichment/depletion, the overall distribution of Hf-Nd isotopes in World river silts is expected to largely reflect the average composition of terrestrial igneous rocks. 


\subsection{Behaviour of $\mathrm{Hf}$ isotopes during basalt weathering}

Except for some minor decoupling in mid-ocean ridge basalts, the Sm-Nd and Lu-Hf isotopic systems are generally well correlated in basalts and other mantle-derived rocks (e.g. Chauvel and Blichert-Toft, 2001). To date, however, there is little information available about the behaviour of $\mathrm{Hf}$ isotopes during basalt weathering. An investigation of the behaviour of radiogenic isotopes along a laterite profile derived from Neogene basalts in Hainan (South China) showed that substantial Hf remobilisation could occur during intense chemical weathering, accompanied by isotopic variations (Ma et al., 2010). In contrast, a few series of experiments conducted on both modern and ancient oceanic basalts suggested instead that leaching of basaltic rocks only had negligible effect on Hf isotopes (Thomson et al., 2008; Silva et al., 2010). In this study, as expected, volcanogenic sediments plot in the upper-right corner of the broad correlations defined by World river clays and silts (Fig. 3). Our results suggest however that basalt weathering can lead to significant Hf-Nd isotopic decoupling between clays and silts. While the Waikato River sample does not exhibit any particular grain-size dependent Hf-Nd isotopic variability (\#48, Table 2), the clay fractions transported by rivers from the Tertiary volcanic province in Northern Ireland are significantly more radiogenic in Hf isotopes than corresponding silts (Fig. 3). To provide further constraints on the behaviour of $\mathrm{Hf}$ during basalt weathering, we have compiled Lu and $\mathrm{Hf}$ mineral-liquid partition coefficient data $(\mathrm{Kd})$ for most common basalt-forming minerals (GERM database; earthref.org/GERM/). These data are presented in Fig. 5 as $\mathrm{Kd}_{\mathrm{Lu}} / \mathrm{Kd}_{\mathrm{Hf}}$ ratios, together with data for granite-forming minerals previously reported by Bayon et al. (2006). Similar to what was proposed for granitic/granitoid rocks, our new compilation suggests that easily alterable minerals in volcanic rocks (e.g. apatite, sphene, olivine) exhibit $\mathrm{Lu} / \mathrm{Hf}$ ratios higher than less alterable rock-forming minerals (e.g. pyroxenes, amphiboles and feldspars) and, to an even greater extent, than resistant opaque minerals (e.g. spinel, ilmenite). As discussed below, this relationship provides further insight into the behaviour of $\mathrm{Hf}$ isotopes during basalt weathering.

First, with time and radioactive decay, olivine and accessory Lu-rich minerals (sphene, apatite) are expected to display a radiogenic $\varepsilon_{\mathrm{Hf}}$ signature compared to other basalt-forming minerals. Their alteration during the early steps of basalt weathering is likely to be accompanied with formation of clays having similarly radiogenic Hf isotopic signatures. In 
order to test the validity of this hypothesis, we have estimated the average ${ }^{176} \mathrm{Lu} /{ }^{177} \mathrm{Hf}$ ratio of the weathered basalt fraction that would account for the $\varepsilon_{\mathrm{Hf}}$ compositions measured in this study for Northern Ireland river clays. This can be done using the general equation of radioactive decay for the Lu-Hf system, the presumed present-day ${ }^{176} \mathrm{Hf} /{ }^{177} \mathrm{Hf}$ value of corresponding source rocks (inferred from measured $\mathrm{Nd}$ isotopic compositions), and considering a large range of potential bulk-rock ${ }^{176} \mathrm{Lu} /{ }^{177} \mathrm{Hf}$ ratios $(0.005-0.03$ estimated from literature data; e.g. Vervoort and Blitchert-Toft, 1999). The obtained calculated ${ }^{176} \mathrm{Lu} /{ }^{177} \mathrm{Hf}$ ratios cluster around 0.15-0.30, which range between published values for olivine mineral separates (about 0.02; Lapen et al., 2013) and apatite (1 to 5; Söderlund et al., 2004). This finding would be consistent with the hypothesis that preferential alteration of Lu-rich minerals can partly explain the radiogenic Hf isotopic compositions of Northern Ireland river clays relative to corresponding silt-size fractions. In addition to these easily alterable phases, volcanic glass represents another particularly unstable constituent of volcanic rocks (e;g. Colman, 1982). Although no partition coefficient data are available for volcanic glass in the GERM database (Fig. 5), its alteration probably also affects to some extent the Hf isotopic signature of associated weathering products. In comparison to the $\sim 50 \mathrm{Ma}$ British Tertiary province, the Waikato River basin is characterized by much younger volcanic activity (e.g. Manville, 2002), suggesting that rock-forming minerals in this area may not have yet developed any significant Hf isotopic heterogeneity, and thereby possibly explaining the absence of grain-size $\varepsilon_{\mathrm{Hf}}$ decoupling in the studied sediment sample.

\section{In addition, spinel and ilmenite, i.e. the minerals displaying the lowest $\mathrm{Kd}_{\mathrm{Lu}} / \mathrm{Kd}_{\mathrm{Hf}}$ ratios, range} among the most resistant minerals in basaltic rocks (e.g. Colman, 1982), in addition to being also relatively enriched in Hf (up to $~ 40$ ppm; Erlank et al., 1978). Similar to zircon, both spinel and ilmenite are also characterized by high density $\left(>4 \mathrm{~g} / \mathrm{cm}^{3}\right)$, and are preferentially concentrated in bedload sediments (e.g. Garzanti et al., 2010). Therefore, by analogy with the 'zircon effect' observed in granitic/granodioritic settings, we propose that preferential sorting of these highly-resistant accessory minerals during sediment transport also accounts, at least to some extent, for the observed $\varepsilon_{\mathrm{Hf}}$ decoupling between clays and silts in our river sediments from Northern Ireland. Additional study would be needed to better understand the factors controlling the behaviour of Hf-Nd isotopes during basalt weathering. However, the abovementioned hypotheses would be consistent with evidence that the silt-size fractions for 
samples collected from volcanic provinces display both lower Lu/Hf ratios (0.075 \pm 0.020$)$ and higher Hf concentrations (5.4 $\pm 1.2 \mathrm{ppm})$ than corresponding clay-size fractions $(0.131 \pm$ 0.050; $3.1 \pm 0.8$ ppm; Table S2).

\subsection{Significance of the new Clay Array}

The new Clay Array defined in this study $\left(\varepsilon_{\mathrm{Hf}}=0.78 \times \varepsilon_{\mathrm{Nd}}+5.23\right)$ plots between the 'Zirconfree sediment array' $\left(\varepsilon_{\mathrm{Hf}}=0.91 \times \varepsilon_{\mathrm{Nd}}+3.1\right.$; Bayon et al., 2009a) and the 'Clay-sized array' reported previously for Chinese and Mongolian dust particles $\left(\varepsilon_{\mathrm{Hf}}=0.45 \times \varepsilon_{\mathrm{Nd}}+2.85\right.$; Zhao et al., 2014) (Fig. 1). Previously, the 'Zircon-free sediment array' was defined as the diffuse Hf-Nd isotopic correlation for fine-grained marine sediments from both margin and deepocean settings, and shales of various stratigraphic ages, but without any grain-size distinction. Because sediment transport and associated mineralogical sorting typically leads to zircon depletion in fine-grained sediments (Patchett et al., 1984), this latter array hence simply represents the 'zircon-free' (or zircon-poor) detrital component of the eroded upper continental crust. In contrast, clay-size fractions in sedimentary rocks are mainly composed of weathering products. As a consequence, the Hf-Nd isotopic compositions of World river clays (this study) and dust clays from Chinese and Mongolian deserts (Chen et al, 2013; Zhao et al., 2014) are likely to be produced by incongruent weathering of bulk silicate rocks, rather than by zircon depletion alone. In this study, the cumulative area of the investigated river basins accounts for more than $30 \%$ of the entire continental area that drains into the global ocean (Bayon et al., 2015). To a lesser extent, the Asian loess/dust samples used in the new Clay Array also incorporate information about a substantial portion of the upper continental crust. Therefore, the new Clay Array in the $\varepsilon_{\mathrm{Hf}} \mathrm{Vs}$. $\varepsilon_{\mathrm{Nd}}$ diagram can be taken as representative of the average Hf-Nd isotopic signature of the weathered upper continental crust. In other words, it provides a reliable estimate for the weathered Terrestrial Array.

\subsection{Factors controlling the Hf-Nd isotopic variability in World river clays}

Despite being relatively well correlated, the $\mathrm{Hf}$ and $\mathrm{Nd}$ isotopic compositions of World river clays display some apparent dispersion relative to the Clay Array (Fig. 3). Below, using a measure of the vertical $\varepsilon_{\mathrm{Hf}}$ deviation from the Clay Array ( $\Delta \varepsilon_{\mathrm{Hf}}$ clay), we investigate various 
factors (e.g. zircon effect, lithology, weathering, climate) that could possibly explain this dispersion (Table 2). In this study, positive and negative $\Delta \varepsilon_{\mathrm{Hf}}$ clay values correspond to samples plotting above and below the Clay Array, respectively, with maximum and minimum values of + 3.6 (Rio Caura, \#37) and -11.5 (Orinoco, \#10). The uncertainty associated with calculated $\Delta \varepsilon_{\text {Hf clay }}$ values, inferred from the analysis of the Loire River samples, is estimated at about $\pm 0.5 \varepsilon$, which corresponds to one standard deviation (1 SD) for the corresponding average $\Delta \varepsilon_{\text {Hf clay }}$ value of -2.1 (Table 1 ). This uncertainty is relatively small compared to the observed $\Delta \varepsilon_{\mathrm{Hf}}$ clay range for World river clays (from about -12 to +4 ; Table 2), hence suggesting that this index can provide reliable information about processes operating at the catchment scale.

Zircon effect: While Zr concentrations in our World river clays are significantly lower than in corresponding silt fractions (Table S2), a recent study based on automated scanning electron microscopy has suggested that zircons could dominate the Hf budget in deep-sea sediments, even in the finest grain-size fractions (Marchandise et al., 2013). The observed $\varepsilon_{\mathrm{Hf}}$ variability in World river clays could hence be possibly related to the presence of small $(<2 \mu \mathrm{m})$ zircon grains that would shift Hf isotopic compositions towards more unradiogenic signatures. In this study, no apparent correlation was observed between $\Delta \varepsilon_{\mathrm{Hf}}$ clay and various indicators of zircon concentration in clay-size fractions (e.g. $\mathrm{Zr}$ contents, $\mathrm{Nd} / \mathrm{Hf}$ and $\mathrm{Zr} / \mathrm{SiO}_{2}$ ratios; graphs not shown here) that would tend to support this hypothesis. We do not rule out the possibility that small zircon grains may be present in our clay fractions. This is actually probably the case for the Orinoco sample. But most likely, our procedure for separating clays from silts by centrifugation also probably led to preferential settling of small (clay-size) dense heavy minerals. This would hence explain their relative underrepresentation in our World river clay fractions. As a consequence, we are confident that the presence of zircons, or of any other heavy mineral phase, does not account for most of the observed Hf isotopic variability in our river clays.

Role of lithology: A second hypothesis would be that the observed $\varepsilon_{\mathrm{Hf}}$ dispersion in clays is related to preferential weathering of particular rock types on continents. Many of the rivers investigated in this study drain watersheds characterized by a wide diversity of lithologies. 
Similar to what was proposed to explain the subtle decoupling of $\mathrm{Nd}$ isotopes between clayand silt-size fractions in large river systems (Bayon et al., 2015), preferential alteration of volcanic rocks relative to other rock types could lead to overrepresentation of volcanogenic clays in the fine-grained suspended load transported to the ocean, hence possibly leading to export of clays having particularly high $\varepsilon_{\mathrm{Hf}}$ signatures. To investigate the potential role of lithology, we compared the $\Delta \varepsilon_{\mathrm{Hf}}$ clay values obtained for rivers from North-West and Northern Ireland (Fig. 2). The rivers draining mixed/sedimentary formations (Shannon \#28, Blackwater \#33, Moyola \#44) and the Precambrian shield of North-West Ireland (Foyle \#44, Swilly \#46) all display similar $\Delta \varepsilon_{\mathrm{Hf}}$ clay values (mean $-1.4 \pm 0.41 \mathrm{SD}$ ). In contrast, the rivers from the Tertiary volcanic province (Maine \#50, Six-Mile \#51, Glenariff \#52) are characterized by significantly higher $\Delta \varepsilon_{\mathrm{Hf}}$ clay $(3.3 \pm 0.21 \mathrm{SD})$. The clay-size fraction from Lower River Bann (\#49) exhibits an intermediate value $\left(\Delta \varepsilon_{\mathrm{Hf} \text { clay }}=1.5\right.$; Table 1$)$, in agreement with evidence that its $\mathrm{Nd}$ isotopic composition $\left(\varepsilon_{\mathrm{Hf}}=-8.9\right)$ also points towards a mixed sediment provenance. Considering that basalts weather relatively fast compared to other rocks on continents, all the above suggests that the presence of large volcanic outcrops in any given basin is likely to influence the $\varepsilon_{\mathrm{Hf}}$ signature of corresponding river clays. This hypothesis would be supported by evidence that the Fraser River basin (\#17), characterized by large occurrence of basaltic rocks (about $40 \%$ of the watershed; Peucker-Ehrenbrink et al., 2010), and to a lesser extent the Nile River (\#4), also display relatively high $\Delta \varepsilon_{\text {Hf clay }}$ values (i.e. 3.1 and 1.2, respectively).

In addition, silicate weathering processes in 'old' cratonic regions could also lead to release of radiogenic Hf-isotope signatures compared to younger rock formations, simply as a consequence of a longer time-integrated radioactive decay within each rock-forming mineral. At first sight, this hypothesis would not be supported by the fact that our World river clays define altogether a strong linear correlation $\left(\mathrm{R}^{2}=0.87\right.$; excepted the Orinoco sample), without showing any particular age-related trend (as inferred from corresponding $\varepsilon_{\mathrm{Nd}}$ values) towards more positive $\varepsilon_{\mathrm{Hf}}$ vertical deviations relative to the Clay Array. However, one cannot exclude that this effect may explain, at least partly, some of the positive $\Delta \varepsilon_{\mathrm{Hf}}$ clay values encountered in clay-size sediments from Scandinavia for example (e.g Lule \#41; Tana \#42). 
Role of weathering and climate: The third (and probably last) possible explanation that could account for the observed $\varepsilon_{\mathrm{Hf}}$ variability in World river clays is the degree of chemical weathering, as proposed in earlier studies (Bayon et al., 2009a; Bayon et al., 2012). As shown in Fig. 6, $\Delta \varepsilon_{\mathrm{Hf}}$ clay exhibits a positive correlation with corresponding values for chemical index of alteration (CIA), hence suggesting a possible causal link between the $\mathrm{Hf}$ isotopic composition of clays and chemical weathering intensity. This is also further supported when plotting $\Delta \varepsilon_{\mathrm{Hf}}$ clay against modern climatic parameters for the corresponding drainage basins (Fig. 6). Except for a few cases (e.g. Fraser \#17), clay-size fractions from river basins characterized by mean annual temperatures (MAT) $>20^{\circ} \mathrm{C}$ and annual rainfall (MAP) $>1250$ mm all exhibit positive $\Delta \varepsilon_{\text {Hf clay }}$ values, and vice versa (Fig. 6). This finding echoes the results from a former study that reported data for filtered river waters in Switzerland, suggesting a link between the degree of Hf isotopic decoupling during weathering and continental runoff (Rickli et al., 2013).

In our study, the degree of relationship between $\Delta \varepsilon_{\mathrm{Hf}}$ clay and climatic parameters was assessed using multiple regression analysis, with $\Delta \varepsilon_{\mathrm{Hf}}$ clay as dependent variable, and temperature (T) and rainfall (P) as independent variables. To avoid any potential influence from zircon contamination or lithology effect, this regression analysis excluded the Orinoco sample (contaminated by the presence of zircons) and rivers draining volcanic provinces (including the Fraser River). The obtained regression line is characterized by the following equation: $\Delta \varepsilon_{\mathrm{Hf} \text { clay (Predicted) }}=-3.92+0.00096 \times \mathrm{P}(\mathrm{mm})+0.12 \times \mathrm{T}\left({ }^{\circ} \mathrm{C}\right)$; with $\mathrm{R}^{2}=0.52$, which indicates that about $50 \%$ of the variation in $\Delta \varepsilon_{\mathrm{Hf}}$ clay can be explained by climatic parameters. Note that the obtained relationship is associated with a low p-value $(<0.05)$ both for rainfall $(0.02)$ and temperature (0.001), hence suggesting that it is statistically significant. Detailed examination of the residuals produced from the regression analysis (see 'Res.' column in Table 2) shows that the most significant differences between predicted and observed $\Delta \varepsilon_{\text {Hf clay }}$ values (up to 6 epsilon units) generally occur in cold and dry river basins, characterized by MAT $<\sim 8{ }^{\circ} \mathrm{C}$ and MAP < 750 mm, such as the Kiiminkijoki (\#43), Narva (\#36), Amu-Darya (\#14), Northern Dvina (\#16), or Tana (\#42) rivers (Fig. 7). In all other river systems, the difference between predicted and measured values is generally much smaller, with an average value of $0.7 \pm 0.5$ epsilon units. This observation suggests that while climatic parameters probably play an important role in controlling the extent of Hf-Nd isotopic decoupling in clay minerals produced under warm and humid conditions, other factors are likely to govern their distribution in colder and dryer environments. Future studies will be required to further 
determine the processes that are controlling Hf-Nd isotope distribution in sediments from such cold and dry source areas. In the context of the sub-Arctic river basins investigated in this study (i.e. MacKenzie \#7, Lule \#41, Tana \#42), all characterized by MAT $<-2^{\circ} \mathrm{C}$, the presence of glacial conditions could result in particularly active chemical weathering processes (Anderson et al., 1997), promoted by intense surface grinding, which could possibly account for the relatively radiogenic Hf isotopic composition of the clay fraction and corresponding positive residual values (> 1.8; Table 2). The Nile (\#4) and Chao Phraya (\#21) rivers represent other exceptions among the warm $\left(>25^{\circ} \mathrm{C}\right)$ river basins, being both characterized by clays with high residual values (> 1.4; Table 2; Fig. 7). However, as discussed in the above section, these anomalously high $\Delta \varepsilon_{\text {Hf clay }}$ values could be related to the presence of large volcanic outcrops in corresponding watersheds (e.g. Peucker-Ehrenbrink et al., 2010; Bayon et al., 2015).

Based on the above discussion, therefore, we propose that the distribution of Hf-Nd isotopes in World river clays, while being influenced by the lithology of corresponding drainage basins, is probably controlled, to some extent, by climatic parameters, especially in warm and humid catchment areas. The implications and potential limitations of this finding are discussed below.

\subsection{Implications and perspectives for the use of $\mathrm{Hf}$ isotopes as paleoenvironmental proxies}

The temperature and rainfall dependence of the degree of chemical weathering of riverborne material have been already suggested in previous works (e.g. Canfield, 1997; Gaillardet et al., 1999a). Our study however represents the first evidence that Hf isotopes can also represent sensitive tracers of the climatic and weathering parameters on continents. Of course, a number of factors other than climate are very likely to affect the overall distribution of Hf isotopes in clay-rich sediments. The potential contamination from 'small' zircons and volcanogenic clays has been already discussed in the above section. As mentioned above, the lithology of drainage basins, and in particular the presence of mantle-derived igneous rocks that are often associated with large heterogeneities in bulk Lu/Hf ratios, will also influence the Hf isotopic composition of secondary minerals formed during weathering. In addition to climate, relief also plays a fundamental role in controlling chemical weathering rates (e.g. Edmond and Huh, 1997; West et al., 2005). An inverse relationship is generally observed 
between physical denudation rates and the degree of chemical weathering (e.g. Gaillardet et al.,1999b). In mountainous regions, high rates of mechanical erosion are generally accompanied by the export of poorly weathered material, while lowlands are usually characterized by low weathering rates, but more intensively weathered soils. In this study, no particular correlation was observed between relief parameters and $\Delta \varepsilon_{\mathrm{Hf}}$ clay. However, for any given range of climatic parameters, one would probably expect that high denudation rates of freshly eroded silicate material in mountainous areas are associated with enhanced release of radiogenic Hf from the alteration of easily dissolvable Lu-rich minerals, and ultimately with clays having higher $\varepsilon_{\mathrm{Hf}}$ values. In contrast, intense chemical reactions in highly weathered soil sequences of tropical lowlands should favour preferential alteration of more resistant minerals, such as feldspar, and hence lead to weathering products having more unradiogenic Hf (as predicted from Fig. 5). This hypothesis would be supported by the fact that two samples characterized by particularly low $\Delta \varepsilon_{\text {Hf clay }}$ values (Narva \#36, Kiiminkijoki \#43; see Fig. 6) come from rivers draining very flat coastal plains (Milliman and Farnworth, 2011).

Importantly, however, the positive relationship observed in Fig. 6 between the degree of alteration of river clays (CIA) and $\Delta \varepsilon_{\text {Hf clay }}$ appears to go in opposite direction to what would be predicted on the basis of the simple correlation identified between $\mathrm{Lu} / \mathrm{Hf}$ ratios and the sequence of alteration of common rock-forming minerals (Fig. 5). Clearly, further studies would be required to better identify the processes that cause the observed relationship. In particular, future work should aim at documenting the behaviour of Hf during weathering through investigation of soil profiles from various environments. In this study, we speculate that the observed relationship between the degree of alteration of river clays and $\Delta \varepsilon_{\mathrm{Hf}}$ clay is related to some extent to cycling of Lu-rich phosphate minerals in soils. Previous studies have shown that alteration of poorly resistant accessory minerals such as allanite and apatite leads to formation of secondary phosphate minerals in soils (e.g. florencite, rhabdophane; Banfield and Eggleton, 1989). These secondary minerals lead to sequestration of substantial amounts of REE and Th in soils (Banfield and Eggleton, 1989; Aubert et al., 2001), and it is also very likely that they incorporate a large fraction of radiogenic Hf released during the early stages of chemical weathering too. While these secondary phases are more stable than their corresponding primary minerals in soils, previous work showed that they could be altered in highly weathered soils (Banfield and Eggleton, 1989). Alteration of these potentially very radiogenic secondary phosphate minerals under intense weathering conditions, and subsequent incorporation/adsorption onto clays, would represent a plausible 
mechanism for the observed relationship between the degree of alteration of river clays and $\Delta \varepsilon_{\mathrm{Hf}}$ clay. In this study, however, no correlation was identified between the Hf isotopic composition of clay-size fractions (or $\Delta \varepsilon_{\mathrm{Hf} \text { clay }}$ ) and elemental ratios such as $\mathrm{Lu} / \mathrm{Hf}$ that would directly support the above-mentioned hypothesis, so this would remain to be tested in the future. Nevertheless, it would be in agreement with the observation that secondary phosphate phases (monazite) can be found in close association with neoformed halloysite and kaolinite (Nicaise et al., 1996).

In major river systems and large sedimentary basins, another potential complication can arise from recycling of clays derived from former sedimentary cycles (e.g. Gaillardet et al., 1999a). While this issue certainly represents a major concern for the use of Hf isotopes (or any other geochemical proxies) in clay-rich sediments as weathering/climatic tracers, a recent study of Phanerozoic shales collected along a latitudinal transect in the Appalachian Mountains (NE America) has shown that the degree of shale weathering was still clearly correlated with present-day climatic parameters (Dere et al., 2013). This latter work would hence suggest that Hf isotopes can still provide constraints on modern weathering and climatic parameters in sedimentary basins. Finally, another potential complication comes from the possible mismatch between the present-day climatic parameters used in this study for comparison, which correspond at best to average values over the last few decades, and the climatic signal preserved in our river clays, which possibly integrate several hundred to thousands of years of weathering history.

Bearing in mind all the above potential limitations, we synthesize our entire set of Hf-Nd isotopic data in Fig. 8 and Table 3, by reporting (after exclusion of samples from volcanic provinces) average $\Delta \varepsilon_{\mathrm{Hf}}$ clay signatures for five different climatic zones defined using arbitrary temperature and rainfall conditions (Table 3). The obtained $\Delta \varepsilon_{\mathrm{Hf}}$ clay estimates show a clear climate-dependency from cold-dry environments (mean $\Delta \varepsilon_{\text {Hf clay }}=-3.0 \pm 2.5$ ) to tropical-wet settings (mean $\Delta \varepsilon_{\text {Hf clay }}=2.1 \pm 1.3$ ). To a first approximation, these average values could serve as a basis for the use of Hf-Nd isotopes in future paleoclimatic and paleoweathering studies. In particular, the application of this $\Delta \varepsilon_{\mathrm{Hf}}$ clay proxy could possibly provide useful information for reconstructing past climates and environments over long geological timescales. 


\section{5- Conclusions}

501

502

503

504

505

506

507

508

509

510

511

512

513

514

515

516

517

518

519

520

521

522

523

524

525

526

527

528

529

530

Our investigation of World river sediments confirms that silicate weathering can lead to significant grain-size decoupling of $\mathrm{Hf}$ and $\mathrm{Nd}$ isotopes. In rivers draining volcanic settings, the observed decoupling probably reflects the combination of preferential alteration of Lu-rich minerals (olivine, apatite) and mineralogical sorting of resistant Hf-rich accessory phases (spinel, ilmenite). World river silts are distributed along the Terrestrial Array, where their HfNd isotopic compositions appear to be largely influenced by the relative abundance of zircons. Instead, the distribution of $\mathrm{Hf}$ and $\mathrm{Nd}$ isotopes in World river clays is mainly controlled by the degree of chemical weathering and, to a lesser extent, the lithology of corresponding drainage basins (presence of volcanic rocks). Together with published data from the literature, river clays define a broad correlation in the $\varepsilon_{\mathrm{Hf}}$ versus $\varepsilon_{\mathrm{Nd}}$ diagram, which we refer to as the Clay Array $\left(\varepsilon_{\mathrm{Hf}}=0.78 \times \varepsilon_{\mathrm{Nd}}+5.23\right)$. An empirical relationship has been identified between the deviation of $\mathrm{Hf}$ isotopic compositions from the Clay Array $\left(\Delta \varepsilon_{\mathrm{Hf}}\right.$ clay $)$ and climatic parameters of river basins (temperature, precipitation). Future studies will now be required to better understand the processes controlling the acquisition of radiogenic Hfisotope signatures in clays, and their relationship with chemical weathering intensity. However, our results suggest that the combined use of $\mathrm{Hf}$ and $\mathrm{Nd}$ isotopes in clay-size sedimentary rocks could serve as a new proxy for reconstructing paleoclimates over geological timescales.

\section{Acknowledgements}

We gratefully acknowledge all our family, friends and colleagues, who provided us with river sediment samples: J. Allard, J. Bayon, C. Bigler, M. Bosq, F. Busschers, G. Calvès, K. Cohen, P. Debrock, P. De Deckker, D. Haynes, P.R. Hill, B. Hoogendoorn, G. Kowaleska, T. Leipe, S. Leroy, L. Lopez, J.P. Lunkla, I. Mendes, D. Meunier, C. Nittrouer, A. Pasquini, V. Ponomareva, Y. Saito, E. Schefuss, E. Sisavath, V. Shevchenko, L. Tiron, D. Toucanne, H. Vallius, S. VanLaningham, A. Wheeler. We also thank the Editor (Martin Frank), Tian-Yu Chen, Jörg Rickli, and one anonymous reviewer for providing constructive comments that contributed to significantly improve the manuscript. This work was funded by the French National Research Agency (ANR), via the ECO-MIST project (\#2010 JCJC 609 01), and by an IEF Marie Curie fellowship (Grant No. FP7-PEOPLE-2012-IEF 327778). 


\section{References}

533

534

535

536

537

Aarons, S.M., Aciego, S.M., Gleason, J.D., 2013. Variable Hf-Sr-Nd radiogenic isotopic compositions in a Saharan dust storm over the Atlantic: Implications for dust flux to oceans, ice sheets and the terrestrial biosphere. Chem. Geol. 349-350, 18-26.

Albarède, F., Simonetti, A.,Vervoort, J.D., Blichert-Toft, J., Abouchami,W., 1998. A Hf-Nd isotopic correlation in ferromanganese nodules. Geophys. Res. Lett. 25, 3895-3898.

Anderson, S.P., Drever, J.I., Humphrey, N.F., 1997. Chemical weathering in glacial environments. Geology 25, 399-402.

Aubert, D., Stille, P., Probst, A., 2001. REE fractionation during granite weathering and removal by waters and suspended loads: $\mathrm{Sr}$ and $\mathrm{Nd}$ isotopic evidence. Geochim. Cosmochim. Acta 65, 387-406.

Banfield, J.F., Eggleton, R.A., 1989. Apatite replacement and rare earth mobilization, fractionation and fixation during weathering. Clays Clay Miner. 37, 113-127.

Bayon, G., German, C.R., Boella, R.M. Milton, J.A. Taylor, R.N. Nesbitt, R.W., 2002. Sr and $\mathrm{Nd}$ isotope analyses in paleoceanography: the separation of both detrital and Fe-Mn fractions from marine sediments by sequential leaching. Chem. Geol. 187, 179-199.

Bayon, G., Vigier, N., Burton, K.W., Brenot, A., Carignan, J., Etoubleau, J., Chu, N.-C., 2006. The control of weathering processes on riverine and seawater hafnium isotope ratios. Geology 34, 433-436.

Bayon, G., Burton, K.W., Soulet, G., Vigier, N., Dennielou, B., Etoubleau, J., Ponzevera, E., German, C.R., Nesbitt, R.W., 2009a. Hf and Nd isotopes in marine sediments: Constraints on global silicate weathering. Earth Planet. Sci. Lett. 277, 318-326.

Bayon, G., Barrat, J.A., Etoubleau, J., Benoit, M., Bollinger, C., Revillon, S., 2009b. Determination of Rare Earth Elements, Sc, Y, Zr, Ba, Hf and Th in Geological Samples by ICP-MS after Tm Addition and Alkaline Fusion. Geostand. Geoanal. Res. 33, 51-62.

Bayon, G., Dennielou, B., Etoubleau, J., Ponzevera, E., Toucanne, S., Bermell, S., 2012. Intensifying Weathering and Land Use in Iron Age Central Africa. Science 335, 12191222.

Bayon, G., Toucanne, S., Skonieczny, C., André, L., Bermell, S., Cheron, S., Dennielou, B., Etoubleau, J., Freslon, N., Gauchery, T., Germain, Y., Jorry, S.J., Ménot, G., Monin, L., Ponzevera, E., Rouget, M.-L., Tachikawa, K., Barrat, J.A., 2015. Rare earth elements and neodymium isotopes in world river sediments revisited. Geochim. Cosmochim. Acta 170, 17-38. 
Blichert-Toft, J., Chauvel, C., Albarède, F., 1997. Separation of Hf and Lu for high-precision isotope analysis of rock samples by magnetic sector-multiple collector ICP-MS. Contrib. Min. Petrol. 127, 248-260.

Bouvier, A., Vervoort, J.D., Patchett, P.J., 2008. The Lu-Hf and Sm-Nd isotopic composition of CHUR: constraints from unequilibrated chondrites and implications for the bulk composition of terrestrial planets. Earth Planet. Sci. Lett. 273, 48-57.

Canfield, D.E., 1997. The geochemistry of river particulates from the continental USA: Major elements. Geochim. Cosmochim. Acta 61, 3349-3365.

Carpentier, M., Chauvel, C., Maury, R.C., Mattieli, N., 2009. The 'zircon effect' as recorded by the chemical and Hf isotopic compositions of Lesser Antilles forearc sediments. Earth Planet. Sci. Lett. 287, 86-99.

Carpentier, M., Weis, D., Chauvel, C., 2014. Fractionation of Sr and Hf isotopes by mineral sorting in Cascadia Basin terrigenous sediments. Chem. Geol. 382, 67-82.

Chauvel, C., Toft, 2001. A hafnium isotope and trace element perspective on melting of the depleted mantle. Earth Planet. Sci. Lett. 190, 137-151.

Chauvel, C., Lewin, E., Carpentier, M., Arndt, N.T., Marini, J.-C., 2008. Role of recycled oceanic basalt and sediment in generating the Hf-Nd mantle array. Nature Geosci. 1, 6467.

Chauvel, C., Garçon, M., Bureau, S., Besnault, A., Jahn, B.M., Ding, Z.L., 2014. Constraints from loess on the Hf-Nd isotopic composition of the upper continental crust. Earth Planet. Sci. Lett. 388, 48-58.

Chen, T.Y., Ling, H.F., Frank, M., Zhao, K.D., Jiang, S.Y., 2011. Zircon effect alone insufficient to generate seawter Nd-Hf isotope relationships. Geochem. Geophys. Geosyst. $12(5)$.

Chen, T.Y., Li, G., Frank, M., Ling, H.F., 2013. Hafnium isotope fractionation during continental weathering: Implications for the generation of the seawater $\mathrm{Nd}-\mathrm{Hf}$ isotope relationships. Geophys. Res. Lett. 40, 916-920.

Chu, N.-C., Taylor, R.N., Chavagnac, V., Nesbitt, R.W., Boella, R.M., Milton, J.A., German, C.R., Bayon, G., Burton, K.W., 2002. Hafnium isotope ratio analysis using multi-collector inductively coupled plasma mass spectrometry: an evaluation of isobaric interference corrections. J. Anal. Atom. Spec. 17, 1567-1574.

Colman, S.M., 1982. Chemical weathering of basalts and andesites: Evidence from weathering rinds. U.S. Geol. Surv. Prof. Pap. 1246, pp 51. 
Dere, A.L., White, T.S., April, R.H., Reynolds, B., Miller, T.E., Knapp, E.P., McKay, L.D., Brantley, S.L., 2013. Climate dependence of feldspar weathering in shale soils along a latitudinal gradient. Geochim. Cosmochim. Acta 122, 101-126.

Edmond, J.M., Huh, Y., 1997. Chemical weathering yields in hot and cold climates, in: Ruddiman, W.F. (Ed.), Tectonic Uplift and Climate Change. Plenum, New York, pp. 558.

Erel, Y., Harlavan, Y., Blum, J.D., 1994. Lead isotope systematics of granitoid weathering. Geochim. Cosmochim. Acta 58, 5299-5306.

Erlank, A.J., Smith, H.S., Marchant, J.W., Cardoso, M.P., Ahrens, L.H., 1978. Hafnium, in: Wedepohl, K.H. (Ed.), Handbook of Geochemistry. Springer-Verlag, Berlin, Heidelberg, New York, pp. 72B-72O.

Gaillardet, J., Dupré, B., Allègre, C.J., 1999a. Geochemistry of large river suspended sediments: Silicate weathering or recycling tracer? Geochim. Cosmochim. Acta 63, 40374051.

Gaillardet, J., Dupré, B., Louvat, P., Allègre, C.J., 1999b. Global silicate weathering and CO2 consumption rates deduced from the chemistry of large rivers. Chem. Geol. 159, 3-30.

Garçon, M., Chauvel, C., 2014. Where is basalt in river sediments, and why does it matter? Earth Planet. Sci. Lett. 407, 61-69.

Garçon, M., Chauvel, C., France-Lanord, C., Huyghe, P., Lavé, J., 2013. Continental sedimentary processes decouple $\mathrm{Nd}$ and Hf isotopes. Geochim. Cosmochim. Acta 121, 177-195.

Garçon, M., Chauvel, C., France-Lanord, C., Limonta, M., Garzanti, E., 2014. Chem. Geol. 364, 42-55.

Garrels, R. M., MacKenzie, F. T., 1971. Evolution of sedimentary rocks. Norton, New York, 397 pp.

Garzanti, E., Ando, S., France-Lanord, C., Vezzoli, G., Censi, P., Galy, V., Najman, Y., 2010. Mineralogical and chemical variability of fluvial sediments 1. Bedload sand (GangaBrahmaputra, Bangladesh). Earth Planet. Sci. Lett. 209, 368-381.

Godfrey, L.V., King, R.L., Zimmermann, B., Vervoort, J.D., Halliday, A.N., 2007. Extreme $\mathrm{Hf}$ isotope signals from basement weathering and, its influence on the seawater Hf-Nd isotope array. 17th Annual V.M. Goldschmidt Conference, Cologne, Germany, August. Geochim. Cosmochim. Acta. 71, A334.

Goldstein, S.L., Hemming, S.R., 2003. Long-lived Isotopic Tracers in Oceanography, Paleoceanography, and Ice-sheet Dynamics. In: Elderfield, H. (Ed.), Holland, H.D., 
Turekian, K.T. (Exec. Eds.), Treatise on Geochemistry, vol. 6, 453-489, ElsevierPergamon, Oxford, pp 625.

Goldstein, S.L., O'Nions, R.K., Hamilton, P.J., 1984. A Sm-Nd isotopic study of atmospheric dusts and particulates from major river systems. Earth Planet. Sci. Lett. 70, 221-236.

Lapen, T.J., Andreasen, R., Righter, M., Irving, A.J., 2013. Lu-Hf Age and Isotope Systematics of Intermediate Permafic Olivine-Phyric Shergottite NWA 2990: Implications for the Diversity of Shergottite Sources. Lun. Planet. Sci. Conf. 44, 2686.

Lupker, M., Aciego, S.M., Bourdon, B., Schwander, J., Stocker, T.F., 2010. Isotopic tracing (Sr, Nd, $\mathrm{U}$ and $\mathrm{Hf}$ ) of continental and marine aerosols in an $18^{\text {th }}$ century section of the Dye-3 ice core (Greenland). Earth Planet. Sci. Lett. 295, 277-286.

Ma, J., Wei, G., Xu, Y., Long, W., 2010. Variations of Sr-Nd-Hf isotopic systematics in basalt during intensive weathering. Chem. Geol. 269, 376-385.

Manville, V., 2002. Sedimentary and geomorphic responses to ignimbrite emplacement: readjustement of the Waikato River after the AD 181 Taupo Eruption, New Zealand. J. geol. 110, 519-541.

Marchandise, S., Robin, E., Ayrault, S., Roy-Barman, M., 2013. U-Th-REE-Hf bearing phases in Mediterranean Sea sediments : implications for isotope systematics in the ocean. Geochim. Cosmochim. Acta 131, 47-61.

McLennan, S.M., 1989. Rare earth elements in sedimentary rocks: Influence of provenance and sedimentary processes. In: Lippin, B.R., McKay G.A. (Eds.), Reviews in Mineralogy. Geochemistry and Mineralogy of Rare Earth Elements, 21, 169-200.

Milliman, J.D., Farnsworth, K.L., 2011. River Discharge to the Coastal Ocean, A global synthesis. Cambridge University Press, 392 pp.

Nesbitt, H.W., Young, G.M., 1982. Early Proterozoic climates and plate motions inferred from major element chemistry of lutites. Nature 299, 715-717.

Opfergelt, S., Cardinal, D., André, L., Delvigne, C., Bremond, L., Delvaux, B., 2010. Variation of $\delta^{30} \mathrm{Si}$ and $\mathrm{Ge} / \mathrm{Si}$ with weathering and biogenic input in tropical basaltic ash soils under mono-culture. Geochim. Cosmochim. Acta 74, 225-240.

Patchett, P.J., White, W.M., Feldmann, H., Kielinczuk, S., Hofmann, A.W., 1984. Hafnium/rare earth element fractionation in the sedimentary system and crustal recycling into the Earth's mantle. Earth Planet. Sci. Lett. 69, 365-378.

Pettke, T., Lee, D.C., Halliday, A.N., Rea, D.K., 2002. Radiogenic Hf isotopic compositions of continental eolian dust from Asia, its variability and its implications for seawater Hf. Earth Planet. Sci. Lett. 202, 453-464. 
Peucker-Ehrenbrink, B., Miller, M.W., Arsouze, T., Jeandel, C., 2010. Continental bedrock and riverine fluxes of strontium and neodymium isotopes to the oceans. Geochem. Geosyst. Geophys. 11, Q03016.

Pinet, P., Souriau, M., 1988. Continental erosion and large-scale relief. Tectonics7, 563-582.

Pourmand, A., Dauphas, N., Ireland, T.J., 2012. A novel extraction chromatography and MCICP-MS technique for rapid analysis of REE, Sc and Y: Revising CI-chondrite and PostArchean Australian Shale (PAAS) abundances. Chem. Geol. 291, 38-54.

Prytulak, J., Vervoort, J.D., Plank, T., Yu, C., 2006. Astoria Fan sediments, DSDP site 174, Cascadia Basin: Hf-Nd-Pb constraints on provenance and outburst flooding. Chem. Geol. 233, 276-292.

Rickli, J., Frank, M., Baker, A.R., Aciego, S., De Souza, G., Georg, R.B., Halliday, A.N., 2010. Hafnium and neodymium isotopes in surface waters of the eastern Atlantic Ocean: Implications for sources and inputs of trace metals to the ocean. Geochim. Cosmochim. Acta 74, 540-557.

Rickli, J., Frank, M., Stichel, T., Georg, R.B., Vance, D., Halliday, A.N., 2013. Controls on the incongruent release of hafnium during weathering of metamorphic and sedimentary catchments. Geochim. Cosmochim. Acta 101, 263-284.

Rudnick, R.L., Gao, S., 2003. The Composition of the Continental Crust. In: Rudnick, R.L. (Ed.), Holland, H.D., Turekian, K.T. (Exec. Eds.), Treatise on Geochemistry, vol. 3, 1-64, Elsevier-Pergamon, Oxford, pp 625.

Silva, I.G.N., Weis, D., Scoates, J.S., 2010. Effects of acid leaching on the Sr-Nd-Hf isotopic compositions of ocean island basalts. Geochem. Geophys. Geosyst. 11 (9).

Söderlund , U., Patchett , P.J., Vervoort, J.D., Isachsen, C.E., 2004. The ${ }^{176}$ Lu decay constant determined by $\mathrm{Lu}-\mathrm{Hf}$ and $\mathrm{U}-\mathrm{Pb}$ isotope systematics of Precambrian mafic intrusions. Earth Planet. Sci. Lett. 219, 311-324.

Taylor S.R., McLennan, S.M., 1985. The Continental Crust: Its composition and Evolution. An Examination of the Geochemical Record Preserved in Sedimentary Rocks. Blackwell Scientific Publications, Oxford, 312 pp.

Thomson, P.M.E., Kempton, P.D., Kerr, A.C., 2008. Evaluation of the effects of alteration and leaching on Sm-Nd and Lu-Hf systematics in submarine mafic rocks. Lithos 104, 164176.

van de Flierdt, T., Goldstein, S.L., Hemming, S.R., Roy, M., Frank, M., Halliday, A.N., 2007. Global Neodymium-Hafnium isotope systematic - Revisited. Earth Planet. Sci. Lett. 259, $432-441$. 
Velde, B., 1995. Origin and Mineralogy of Clays: Clays and the Environment. Springer, Berlin, Heidelberg, 336 pp.

Vervoort, J.D., Blichert-Toft, J., 1999. Evolution of the depleted mantle: Hf isotope evidence from juvenile rocks through time. Geochim. Cosmochim. Acta 63, 533-556.

Vervoort, J.D., Patchett, P.J., Blichert-Toft, J., Albarède, F., 1999. Relationships between LuHf and Sm-Nd isotopic systems in the global sedimentary system. Earth Planet. Sci. Lett. 168, 79-99.

Vervoort, J.D., Plank, T., Prytulak, J., 2011. The Hf-Nd isotopic composition of marine sediments. Geochim. Cosmochim. Acta 75, 5903-5926.

Vlastelic, I., Carpentier, M., Lewin, E., 2005. Miocene climate change recorded in the chemical and isotopic ( $\mathrm{Pb}, \mathrm{Nd}, \mathrm{Hf})$ signature of Southern Ocean sediments. Geochem. Geophys. Geosys. 6, Q03003.

von Strandmann, P.A.E.P., Opferglet, S., Lai, Y.J., Sigfusson, B., Gislason, S.R., Burton, K.W., 2012. Lithium, magnesium and silicon isotope behaviour accompanying weathering in a basaltic soil and pore water profile in Iceland. Earth Planet. Sci. Lett. 339, 11-23.

West, A.J., Galy, A., Bickle, M., 2005. Tectonic and climatic control on silicate weathering. Earth Planet. Sci. Lett. 235, 211-228.

Zhao, W., Sun, Y., Balsam, W., Lu, H., Liu, L., Chen, J., Ji, J., 2014. Hf-Nd isotopic variability in mineral dust from Chinese and Mongolian deserts: implications for sources and dispersal. Sci. Rep. 4, 5837. 
Figure 1. A compilation of published $\mathrm{Hf}$ and $\mathrm{Nd}$ isotopic compositions for fine-grained sediments and other sedimentary rocks. The sediment data (grey circles) include presentday $\varepsilon_{\mathrm{Hf}}$ and $\varepsilon_{\mathrm{Nd}}$ values for: marine sediments (Vervoort et al., 1999; Pettke et al., 2002; Vlastelic et al., 2005; Prytulac et al., 2006; van de Flierdt et al., 2007; Bayon et al., 2009a; Carpentier et al., 2009; Vervoort et al., 2011; Carpentier et al., 2014), river particulates and bedloads (Bayon et al., 2006; Rickli et al., 2013; Garçon et al., 2013; Garçon et al., 2014; Garçon and Chauvel, 2014), loess deposits (Chen et al., 2013; Chauvel et al., 2014) and aeolian dusts (Lupker et al., 2010; Rickli et al., 2010; Aarons et al., 2013; Pourmand et al., 2014; Zhao et al., 2014) The Seawater Array $\left(\varepsilon_{\mathrm{Hf}}=0.55 \times \varepsilon_{\mathrm{Nd}}\right.$ +7.1 ; Albarède et al., 1998) and the present-day Terrestrial Array $\left(\varepsilon_{\mathrm{Hf}}=1.55 \times \varepsilon_{\mathrm{Nd}}+\right.$ 1.21 ; Vervoort et al., 2011) are shown for comparison, together with 3 other correlations identified in previous studies for fine-grained sediments (the 'zircon-free sediment array'; $\varepsilon_{\mathrm{Hf}}=0.91 \times \varepsilon_{\mathrm{Nd}}+3.10$; Bayon et al., 2009a), coarse-grained sediments (the 'zirconbearing sediment array'; $\varepsilon_{\mathrm{Hf}}=1.80 \times \varepsilon_{\mathrm{Nd}}+2.35$; Bayon et al., 2009a), and Mongolian and Chinese dust clays (the ‘clay-sized array'; $\varepsilon_{\mathrm{Hf}}=0.45 \times \varepsilon_{\mathrm{Nd}}+2.85$; Zhao et al., 2014).

Figure 2. Location of studied river-borne sediments. (A,B) The rivers selected for this study include 1) major river systems with watersheds larger than 100,000 $\mathrm{km}^{2}$ (red circles); 2) rivers draining mixed/sedimentary formations with drainage areas smaller than 100,000 $\mathrm{km}^{2}$ (orange diamonds); 3) rivers draining igneous/metamorphic terranes (yellow squares); 4) rivers draining volcanic provinces (purple triangles). (C) Several minor rivers were sampled in North-West and Northern Ireland, draining a large variety of mono-lithological terranes.

Figure 3. Nd and Hf isotopic compositions of World river silts and clays. The new Clay Array $\left(\varepsilon_{\mathrm{Hf}}=0.78 \times \varepsilon_{\mathrm{Nd}}+5.23\right)$ corresponds to the linear regression of World river clays (except for the Orinoco River sample), clay-size fractions of Chinese/Mongolian loess and dusts (Chen et al., 2013; Zhao et al., 2014). Symbols are described in Fig. 2 caption. 
The reference Hf-Nd isotope data for fine-grained sediments (grey circles) are given in Figure 1.

Figure 4. Relationship between $\mathrm{Zr}$ abundances and $\Delta \varepsilon_{\mathrm{Hf}}$ terrestrial in World river silts. $\Delta \varepsilon_{\mathrm{Hf}}$ terrestrial represents the deviation of $\mathrm{Hf}$ isotopic compositions from the present-day Terrestrial Array (Vervoort et al., 2011). The samples characterized by negative $\Delta \varepsilon_{\mathrm{Hf}}$ terrestrial values generally correspond to Zr concentrations higher than UCC value (193 ppm; Rudnick and Gao, 2013), and vice versa. Data for loess (Chauvel et al., 2014) and Ganges river basin sediments (Garçon et al., 2013) are shown for comparison. Symbols: see Figure 3.

Figure 5. Lu-Hf and Sm-Nd mineral-liquid partition coefficient ratios (Kd) for most common granite-forming minerals (modified from Bayon et al., 2006) and basalt-forming minerals (This study; compiled from http://earthref.org/GERM). The grey arrows represent the typical sequences of alteration during weathering of granitic (for details and references, see Fig. 2 of Bayon et al., 2006) and basaltic rocks (Colman, 1982). The minerals exhibiting the highest $\mathrm{Kd}_{\mathrm{Lu}} / \mathrm{Kd}_{\mathrm{Hf}}$ ratios in volcanic rocks (e.g. olivine, apatite) are those that are preferentially dissolved during early basalt weathering. In contrast, two of the most resistant minerals in basaltic rocks (spinel and ilmenite) are characterized by low $\mathrm{Kd}_{\mathrm{Lu}} / \mathrm{Kd}_{\mathrm{Hf}}$. Note that no partition coefficient data is available for volcanic glass, one of the most easily alterable constituent in volcanic rocks.

Figure 6. Relationships between Nd-Hf isotopic compositions in World river clays, the degree of chemical weathering, and climatic parameters. $\Delta \varepsilon_{\mathrm{Hf}}$ clay represents the deviation of Hf isotopic compositions from the new Clay Array (This study). The chemical index of alteration corresponds to $\mathrm{CIA}=\left[\mathrm{Al}_{2} \mathrm{O}_{3} /\left(\mathrm{Al}_{2} \mathrm{O}_{3}+\mathrm{CaO}+\mathrm{Na}_{2} \mathrm{O}+\mathrm{K}_{2} \mathrm{O}\right)\right] \times 100$, expressed in molar proportions (Nesbitt and Young, 1982). The climatic parameters used for comparison include the mean annual temperatures (MAT; ${ }^{\circ} \mathrm{C}$ ) and mean annual precipitation (MAP; mm) 
Figure 7. Comparison between measured (black circles) and predicted (orange diamonds) $\Delta \varepsilon_{\text {Hf clay }}$ values for World river clays. The predicted $\Delta \varepsilon_{\text {Hf clay }}$ values were determined using the regression line determined between $\Delta \varepsilon_{\mathrm{Hf}}$ clay (dependent variable), and temperature ( $\mathrm{T}$ ) and rainfall (P) (independent variables), characterized by the following equation: $\Delta \varepsilon_{\text {Hf clay }(\text { Predicted) }}=-3.92+0.00096 \times \mathrm{P}(\mathrm{mm})+0.12 \times \mathrm{T}\left({ }^{\circ} \mathrm{C}\right)$. The most significant differences between predicted and observed $\Delta \varepsilon_{\mathrm{Hf}}$ clay values (up to 6 epsilon units) generally occur in cold and dry river basins (e.g. Kiiminkijoki, Narva, Amu-Darya, Northern Dvina, and Tana), suggesting that factors other factors are likely to govern their distribution in colder and dryer environments.

Figure 8. Climate dependence of Hf-Nd isotope decoupling in World river clays. Average $\Delta \varepsilon_{\text {Hf clay }}$ values have been calculated for five different climatic zones, defined according to the arbitrary criteria listed in Table 3. 


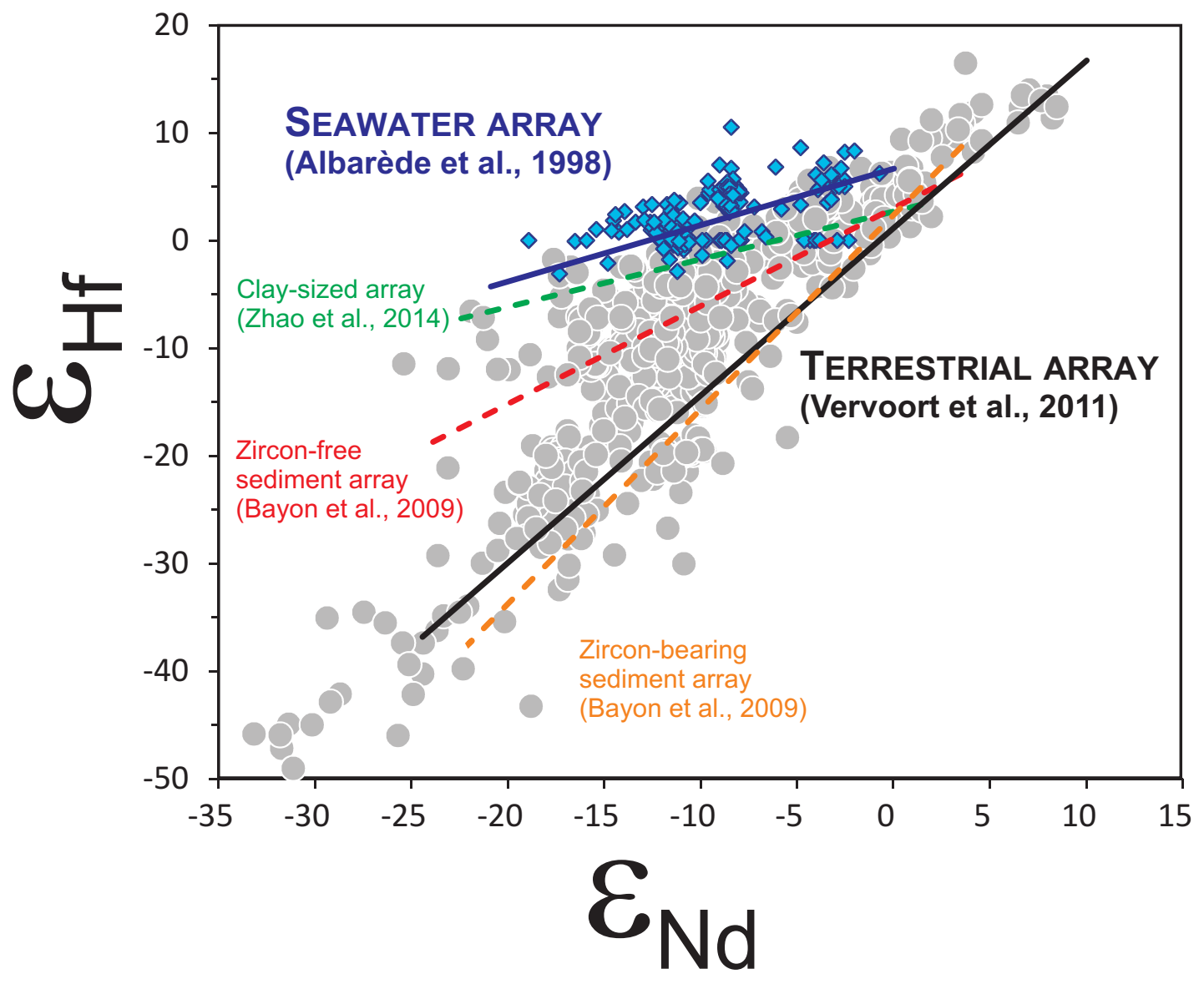

Fig.

1 

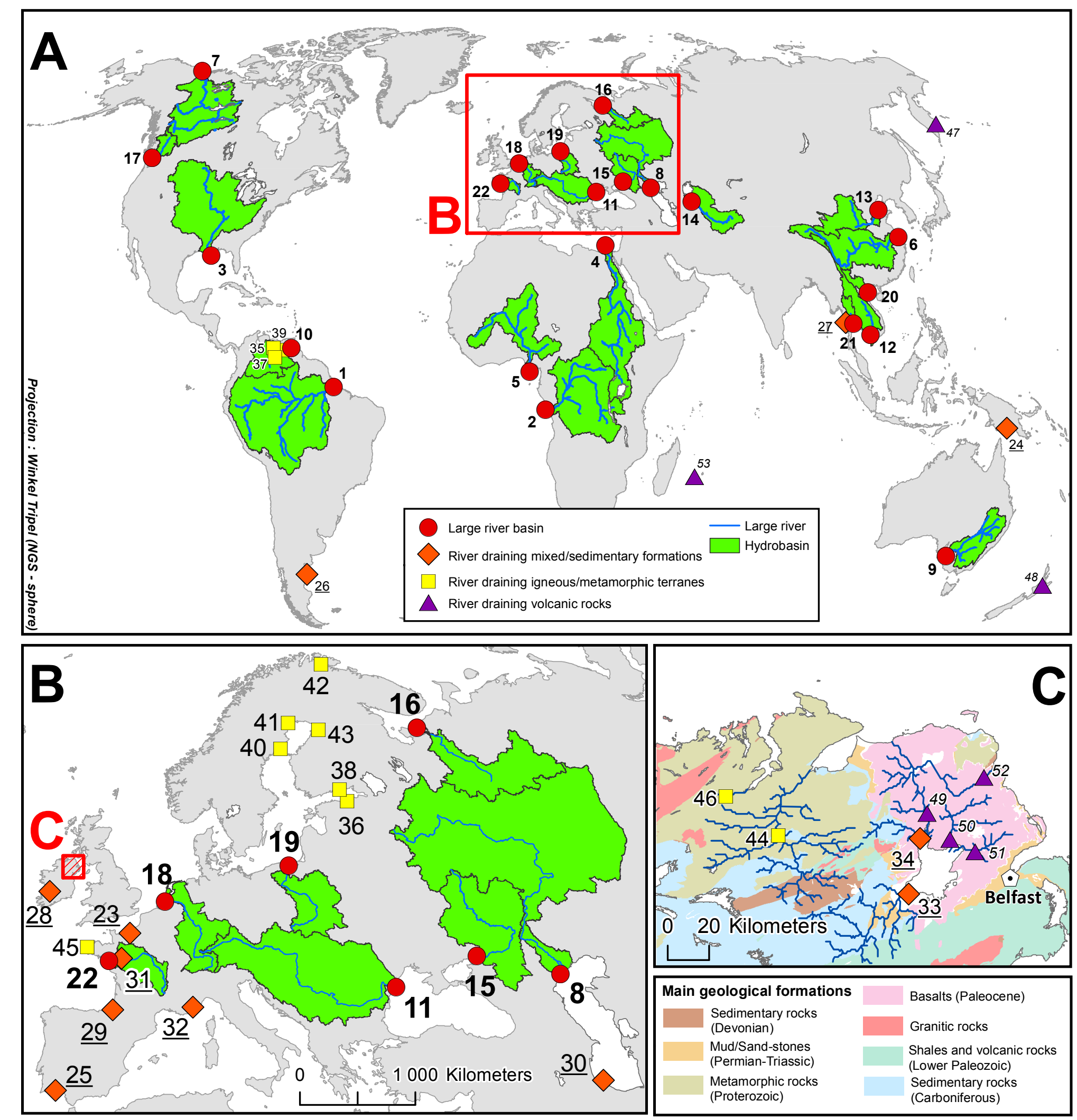


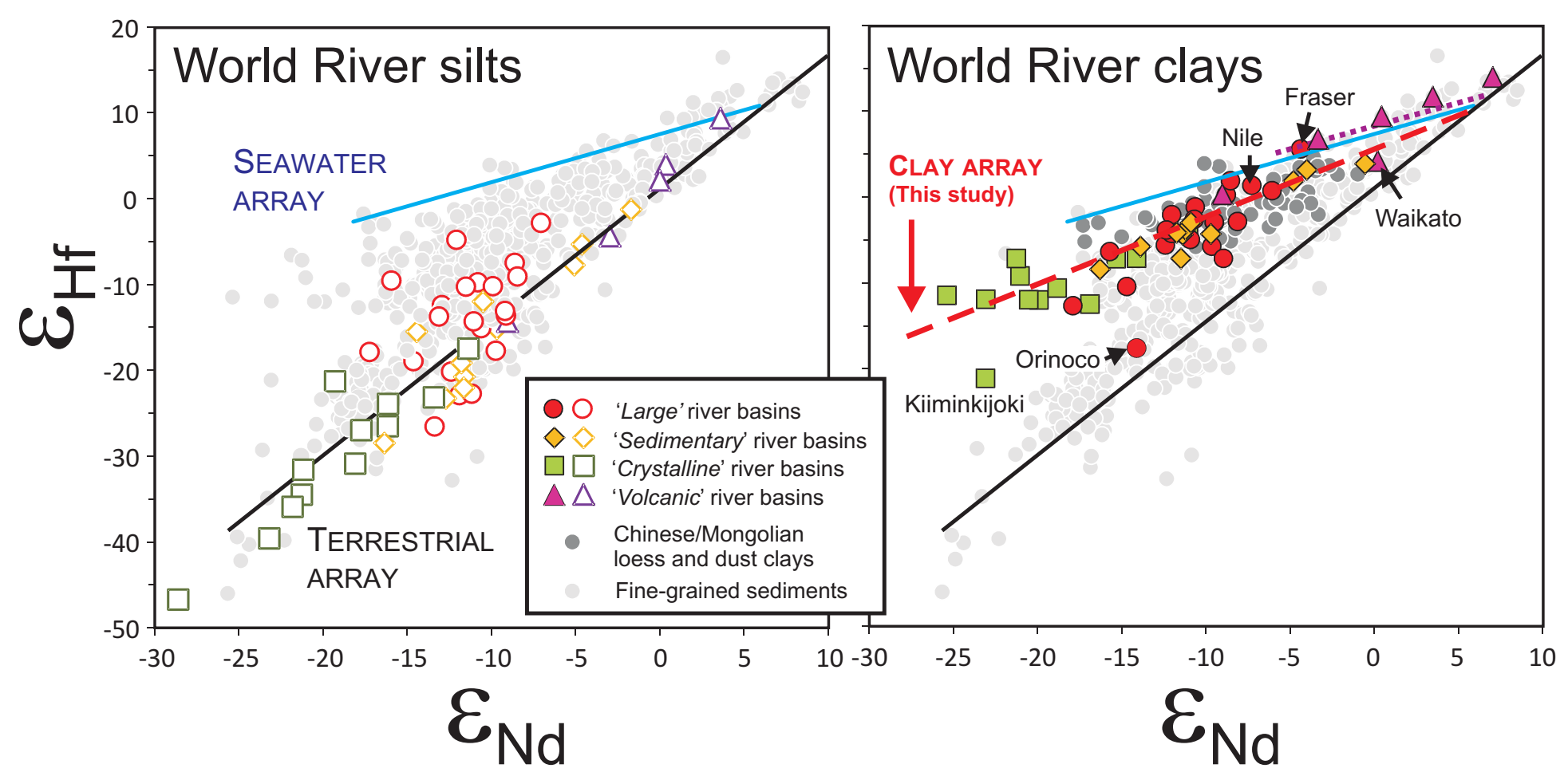

Fig. 3 


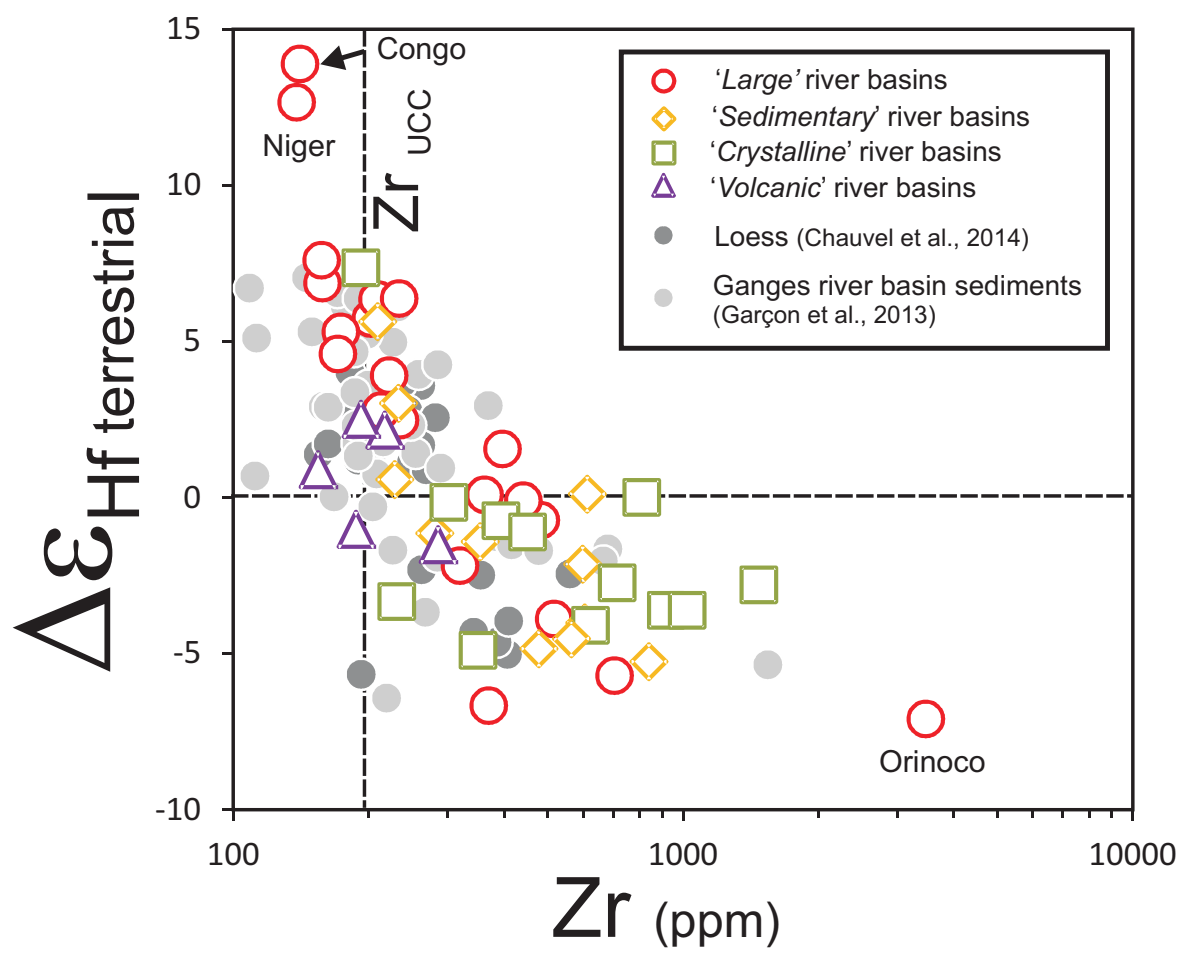

Fig. 4 


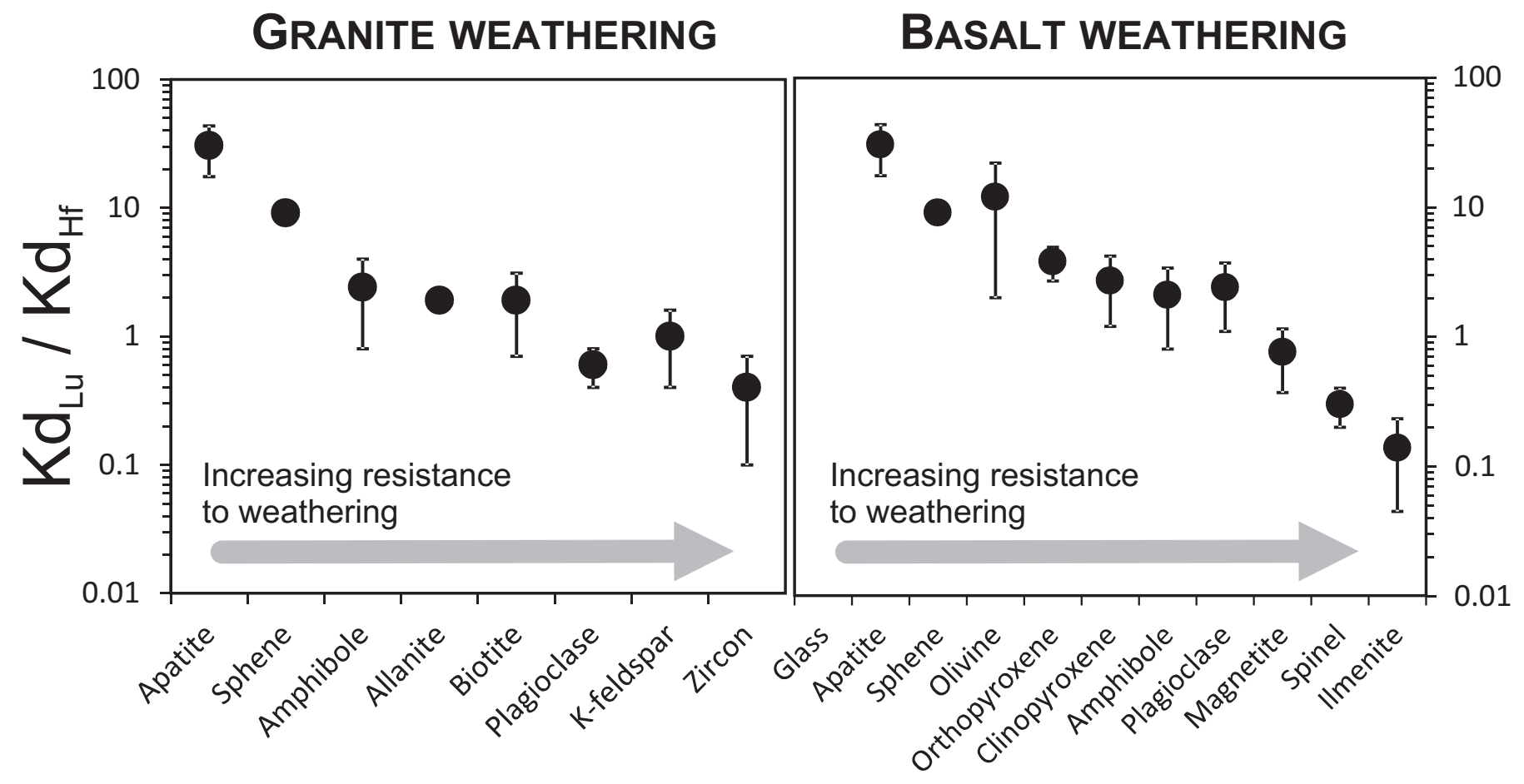

Fig. 5 


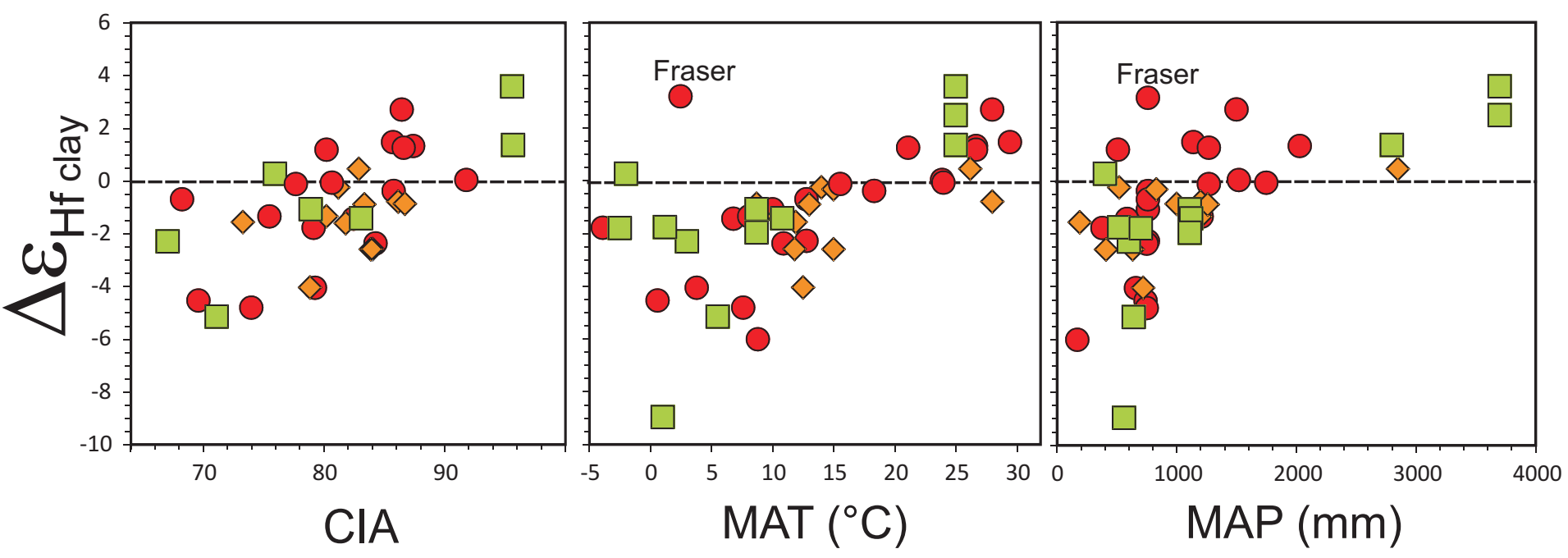

Fig. 6 

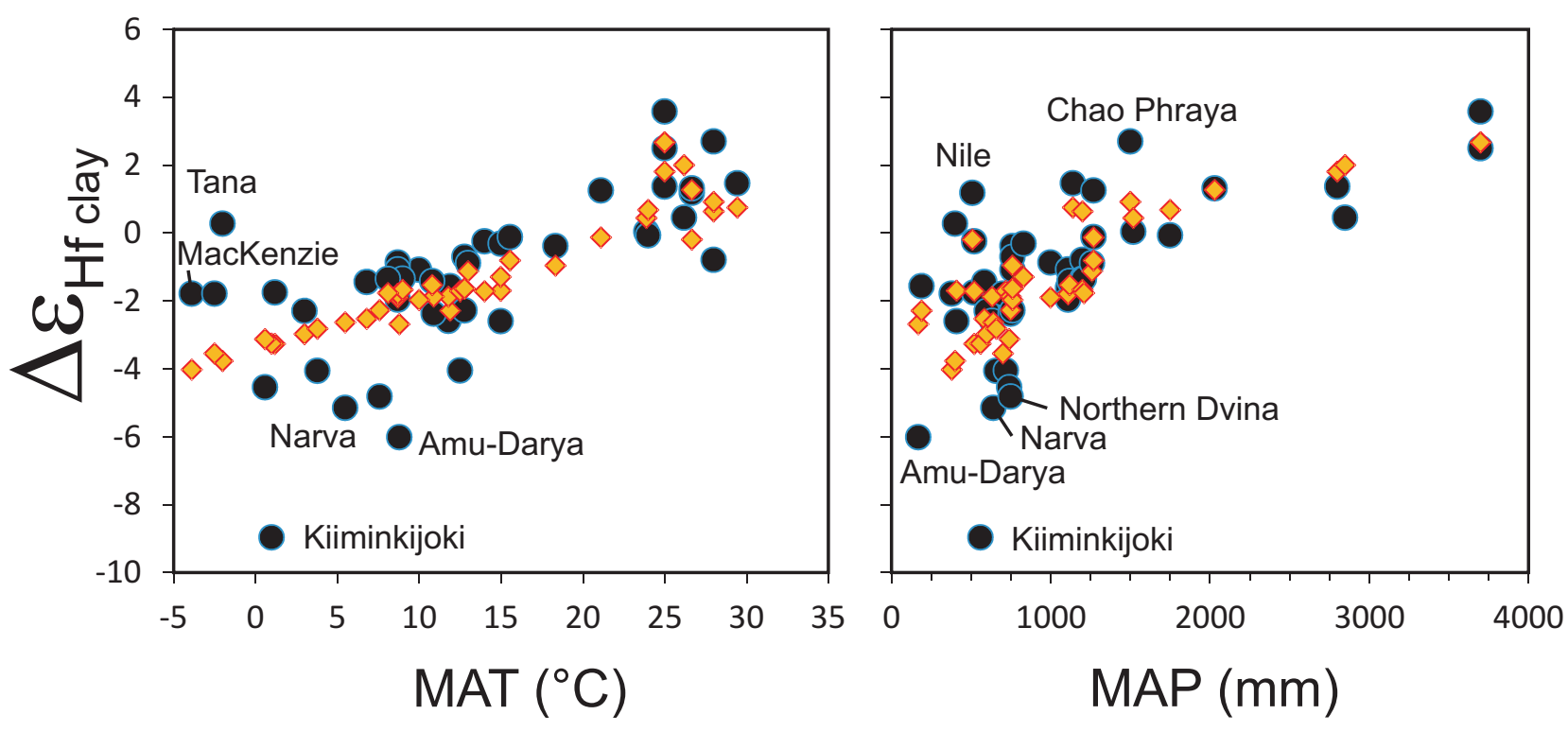

Fig. 7 


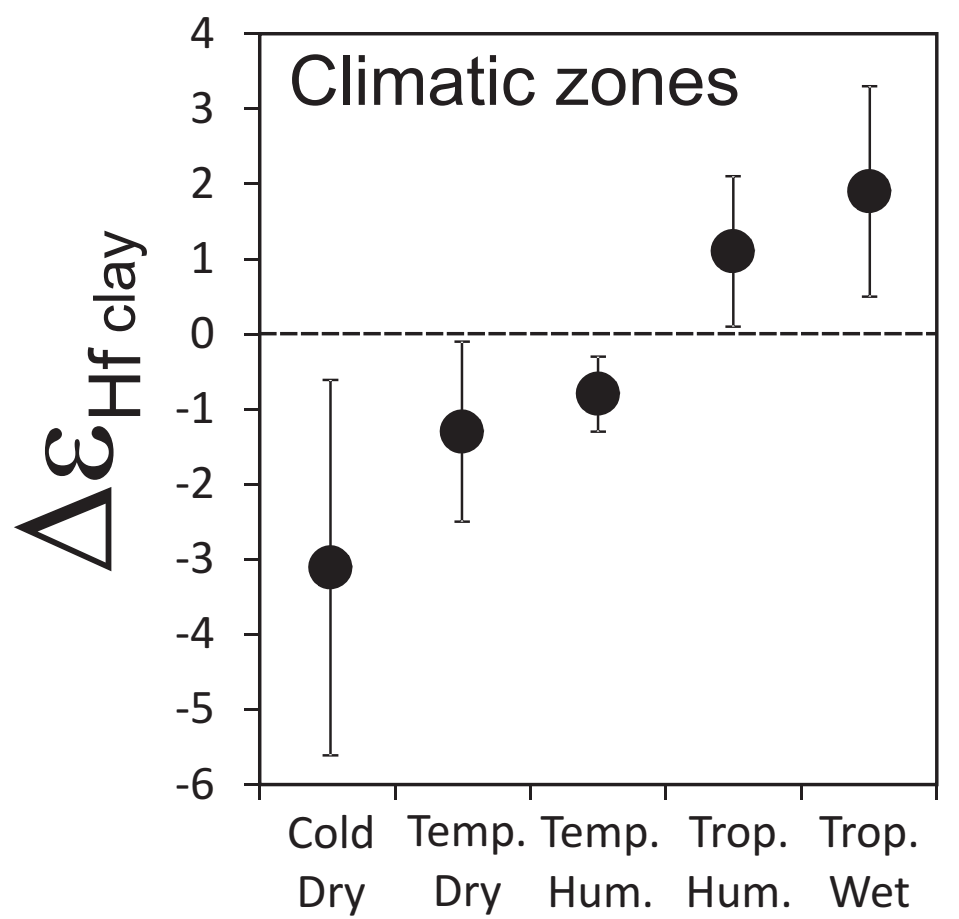

Fig. 8 
Table 1

$\mathrm{Hf}-\mathrm{Nd}$ isotopic compositions of clay-size fractions from the Loire River estuary.

\begin{tabular}{|c|c|c|c|c|c|c|}
\hline Loire_ID & Sampling sites & $\begin{array}{c}{ }^{143} \mathrm{Nd} /{ }^{144} \mathrm{Nd} \\
\pm 2 \mathrm{se} \\
\end{array}$ & $\varepsilon_{\mathrm{Nd}}$ & $\begin{array}{c}{ }^{176} \mathrm{Hf} /{ }^{177} \mathrm{Hf} \\
\pm 2 \mathrm{se} \\
\end{array}$ & $\varepsilon_{\mathrm{Hf}}$ & $\Delta \varepsilon_{\text {Hf clay }}$ \\
\hline Loire_1 & Pont de St-Nazaire & $0.512190 \pm 16$ & -8.6 & $0.282699 \pm 11$ & -3.1 & -1.6 \\
\hline Loire_2 & Donges & $0.512234 \pm 13$ & -7.7 & $0.282685 \pm 6$ & -3.6 & -2.8 \\
\hline Loire_3 & Cordemais & $0.512204 \pm 14$ & -8.3 & $0.282677 \pm 12$ & -3.8 & -2.6 \\
\hline Loire_4 & Pellerin & $0.512196 \pm 16$ & -8.5 & $0.282694 \pm 5$ & -3.2 & -1.9 \\
\hline Loire_5 & Indret & $0.512205 \pm 15$ & -8.3 & $0.282695 \pm 6$ & -3.2 & -1.9 \\
\hline Loire_6 & Port Lavigne & $0.512231 \pm 8$ & -7.8 & $0.282690 \pm 3$ & -3.3 & -2.5 \\
\hline \multirow[t]{2}{*}{ Loire_7 } & Trentemoult & $0.512198 \pm 13$ & -8.4 & $0.282695 \pm 5$ & -3.2 & -1.8 \\
\hline & Average $( \pm 1 \mathrm{sd})$ & & $-8.2 \pm 0.3$ & & $-3.3 \pm 0.3$ & $-2.1 \pm 0.5$ \\
\hline
\end{tabular}


Table 2

$\mathrm{Hf}-\mathrm{Nd}$ isotopic compositions of World river clays and silts.

\begin{tabular}{|c|c|c|c|c|c|c|c|c|c|c|c|c|}
\hline \multirow{2}{*}{$\begin{array}{l}\text { Sample } \\
\text { River }\end{array}$} & \multicolumn{3}{|c|}{ Climatic parameters } & \multicolumn{3}{|c|}{ Silts } & $\Delta \varepsilon_{\mathrm{Hf}}$ & \multicolumn{2}{|c|}{ Clays } & \multicolumn{3}{|c|}{$\Delta \varepsilon_{H f}$} \\
\hline & Zone & $\begin{array}{l}\text { MAT } \\
\left({ }^{\circ} \mathrm{C}\right) \\
\end{array}$ & $\begin{array}{l}\text { MAP } \\
(\mathrm{mm})\end{array}$ & $\begin{array}{c}{ }^{176} \mathrm{Hf} /{ }^{177} \mathrm{Hf} \\
\pm 2 \mathrm{se} \\
\end{array}$ & $\varepsilon_{\mathrm{Hf}}$ & $\varepsilon_{\mathrm{Nd}^{*}}$ & Terr. & $\begin{array}{c}{ }^{176} \mathrm{Hf} /{ }^{177} \mathrm{Hf} \\
\pm 2 \mathrm{se} \\
\end{array}$ & $\varepsilon_{\mathrm{Hf}}$ & $\varepsilon_{\mathrm{Nd}^{*}}$ & Clay & Res. \\
\hline \multicolumn{13}{|l|}{ Large rivers } \\
\hline 1 Amazon & Tr.W & 26.7 & 2030 & $0.282495 \pm 5$ & -10.3 & -10.7 & 5.1 & $0.282738 \pm 4$ & -1.6 & -10.5 & 1.3 & 0.0 \\
\hline 2 Congo & Tr.W & 23.9 & 1520 & $0.282500 \pm 5$ & -10.1 & -15.8 & 13.2 & $0.282591 \pm 4$ & -6.9 & -15.5 & 0.0 & -0.4 \\
\hline 3 Mississippi & Te.D & 12.8 & 760 & $0.282201 \pm 5$ & -20.6 & -12.3 & -2.8 & $0.282631 \pm 4$ & -5.4 & -10.8 & -2.3 & -0.6 \\
\hline 4 Nile & Tr.H & 26.7 & 610 & $0.282270 \pm 6$ & -18.2 & -9.6 & -4.5 & $0.282810 \pm 4$ & 0.9 & -7.1 & 1.2 & 1.4 \\
\hline 5 Niger & Tr.H & 29.4 & 1140 & $0.282635 \pm 6$ & -5.3 & -11.9 & 12.0 & $0.282713 \pm 4$ & -2.6 & -11.9 & 1.5 & 0.7 \\
\hline 6 Yangtze & Te.H & 15.6 & 1270 & $0.282481 \pm 5$ & -10.7 & -11.4 & 5.7 & $0.282697 \pm 7$ & -3.1 & -10.5 & -0.1 & 0.7 \\
\hline 7 MacKenzie & Cold.D & -3.9 & 380 & $0.282382 \pm 6$ & -14.2 & -13.0 & 4.7 & $0.282612 \pm 3$ & -6.1 & -12.2 & -1.8 & 2.2 \\
\hline 8 Volga & Cold.D & 3.8 & 660 & $0.282123 \pm 3$ & -23.4 & -11.8 & -6.4 & $0.282609 \pm 5$ & -6.2 & -9.5 & -4.1 & -1.2 \\
\hline 9 Murray & Te.D & 18.3 & 760 & $0.282691 \pm 6$ & -3.3 & -6.9 & 6.2 & $0.282792 \pm 5$ & 0.2 & -5.9 & -0.4 & 0.6 \\
\hline 10 Orinoco & Tr.H & 23.9 & 1400 & $0.282020 \pm 4$ & -27.0 & -13.2 & -7.8 & $0.282305 \pm 4$ & -17.0 & -13.8 & -11.5 & -11.8 \\
\hline 11 Danube & Te.D & 10.0 & 760 & not analyzed & & & & $0.282714 \pm 12$ & -2.5 & -8.5 & -1.1 & 0.9 \\
\hline 12 Mekong & Tr.H & 21.1 & 1270 & $0.282344 \pm 3$ & -15.6 & -10.5 & -0.6 & $0.282778 \pm 5$ & -0.2 & -8.6 & 1.2 & 1.4 \\
\hline 13 Yellow River & Te.D & 12.8 & 760 & $0.282366 \pm 4$ & -14.8 & -10.9 & 0.9 & $0.282651 \pm 4$ & -4.7 & -11.9 & -0.7 & 0.9 \\
\hline 14 Amu Darya & Cold.D & 8.8 & 170 & $0.282385 \pm 5$ & -14.1 & -9.0 & -1.4 & $0.282569 \pm 6$ & -7.6 & -8.8 & -6.0 & -3.3 \\
\hline 15 Don & Cold.D & 6.8 & 580 & $0.282128 \pm 6$ & -23.2 & -11.0 & -7.3 & $0.282687 \pm 13$ & -3.5 & -9.3 & -1.4 & 1.1 \\
\hline 16 Northern Dvina & Cold.D & 0.6 & 740 & $0.282266 \pm 5$ & -18.4 & -17.1 & 6.9 & $0.282413 \pm 6$ & -13.1 & -17.7 & -4.6 & -1.4 \\
\hline 17 Fraser & Cold.D & 4.4 & 760 & $0.282559 \pm 5$ & -8.0 & -8.5 & 3.9 & $0.282929 \pm 4$ & 5.1 & -4.2 & 3.1 & 5.8 \\
\hline 18 Rhine & Te.H & 8.1 & 1210 & $0.282401 \pm 4$ & -13.6 & -9.1 & -0.7 & $0.282689 \pm 6$ & -3.4 & -9.3 & -1.4 & 0.4 \\
\hline 19 Vistula & Cold.D & 7.6 & 750 & $0.282236 \pm 5$ & -19.4 & -14.5 & 1.8 & $0.282476 \pm 5$ & -10.9 & -14.5 & -4.8 & -2.5 \\
\hline 20 Red River & Tr.W & 24.0 & 1750 & $0.282420 \pm 4$ & -12.9 & -12.8 & 5.7 & $0.282662 \pm 6$ & -4.3 & -12.2 & -0.1 & -0.7 \\
\hline 21 Chao Phraya & Tr.W & 28.0 & 1500 & $0.282482 \pm 5$ & -10.7 & -9.8 & 3.3 & $0.282824 \pm 5$ & 1.4 & -8.4 & 2.7 & 1.8 \\
\hline 22 Loire (Port-Lavigne) & Te.D & 10.9 & 750 & $0.282515 \pm 6$ & -9.6 & -8.3 & 2.1 & $0.282690 \pm 3$ & -3.3 & -7.8 & -2.5 & -0.5 \\
\hline \multicolumn{13}{|c|}{ Rivers draining mixed/sedimentary formations } \\
\hline 23 Seine & Te.D & 12.5 & 720 & $0.282184 \pm 4$ & -21.3 & -11.5 & -4.7 & $0.282569 \pm 4$ & -7.6 & -11.3 & -4.1 & -2.3 \\
\hline 24 Fly & Tr.W & 26.2 & 2850 & $0.282552 \pm 4$ & -8.2 & -4.9 & -1.8 & $0.282861 \pm 4$ & 2.7 & -3.8 & 0.4 & -1.5 \\
\hline 25 Guadiana & Te.D & 15 & 410 & not analyzed & & & & $0.282650 \pm 6$ & -4.8 & -9.5 & -2.6 & -0.9 \\
\hline 26 Chubut & Te.D & 11.9 & 190 & $0.282735 \pm 5$ & -1.8 & -1.6 & -0.5 & $0.282880 \pm 8$ & 3.4 & -0.4 & -1.6 & 0.7 \\
\hline 27 Mae Klong & Tr.H & 28 & 1200 & $0.282333 \pm 4$ & -16.0 & -14.3 & 5.0 & $0.282608 \pm 6$ & -6.3 & -13.7 & -0.8 & -1.4 \\
\hline 28 Shannon & Te.H & 9 & 1200 & $0.282148 \pm 4$ & -22.5 & -11.5 & -5.9 & $0.282647 \pm 6$ & -4.9 & -11.2 & -1.3 & 0.3 \\
\hline 29 Adour & Te.H & 13 & 1260 & $0.282230 \pm 4$ & -19.6 & -11.6 & -2.8 & $0.282664 \pm 5$ & -4.3 & -11.0 & -0.9 & 0.2 \\
\hline 30 Sefid Rud & Te.D & 14 & 520 & $0.282621 \pm 4$ & -5.8 & -4.5 & -0.1 & $0.282824 \pm 4$ & 1.4 & -4.6 & -0.3 & 1.5 \\
\hline 31 Mayenne & Te.D & 11.8 & 630 & $0.282342 \pm 4$ & -15.7 & -9.6 & -2.1 & $0.282649 \pm 5$ & -4.8 & -9.5 & -2.6 & -0.7 \\
\hline 32 Var & Te.D & 15 & 830 & $0.282432 \pm 3$ & -12.5 & -10.4 & 2.4 & $687 \pm 4$ & -3.5 & -10.7 & -0.3 & 1.0 \\
\hline 33 Blackwater & Te.H & 8.7 & 1000 & $0.282113 \pm 5$ & -23.8 & -12.6 & -5.5 & $0.282653 \pm 5$ & -4.7 & -11.6 & -0.9 & 1.0 \\
\hline 34 Moyola & Te.H & 8.7 & 1110 & $0.281965 \pm 3$ & -29.0 & -16.2 & -5.1 & $0.282532 \pm 5$ & -8.9 & -16.1 & -1.6 & 0.2 \\
\hline \multicolumn{13}{|c|}{ Rivers draining igneous/metamorphic terranes } \\
\hline 35 Rio Caroni & Tr.W & 25 & 2800 & $0.281796 \pm 5$ & -35.0 & -21.1 & -3.4 & $0.282511 \pm 4$ & -9.7 & -20.9 & 1.4 & -0.4 \\
\hline 36 Narva & Cold.D & 5.5 & 640 & $0.282095 \pm 5$ & -24.4 & -16.0 & -0.8 & $0.282418 \pm 4$ & -13.0 & -16.7 & -5.2 & -2.5 \\
\hline 37 Rio Caura & Tr.W & 25 & 3700 & $0.281879 \pm 4$ & -32.1 & -21.0 & -0.7 & $0.282569 \pm 4$ & -7.7 & -21.1 & 3.6 & 0.9 \\
\hline 38 Kymijoki & Cold.D & 3 & 600 & $0.282169 \pm 5$ & -21.8 & -19.2 & 6.7 & $0.282432 \pm 4$ & -12.5 & -19.8 & -2.3 & 0.7 \\
\hline 39 Rio Aro & Tr.W & 25 & 3700 & $0.281450 \pm 5$ & -47.2 & -28.5 & -4.3 & $0.282447 \pm 6$ & -12.0 & -25.2 & 2.5 & -0.2 \\
\hline 40 Ume & Cold.D & 1.2 & 520 & $0.282009 \pm 4$ & -27.4 & -17.6 & -1.4 & $0.282471 \pm 5$ & -11.1 & -18.7 & -1.8 & 1.5 \\
\hline 41 Lule & Cold.D & -2.5 & 700 & $0.281898 \pm 5$ & -31.4 & -18.0 & -4.7 & $0.282433 \pm 3$ & -12.4 & -20.4 & -1.8 & 1.8 \\
\hline 42 Tana & Cold.D & -2 & 400 & $0.281756 \pm 5$ & -36.4 & -21.7 & -4.0 & $0.282434 \pm 7$ & -12.4 & -23.0 & 0.3 & 4.0 \\
\hline 43 Kiiminkijoki & Cold.D & 1 & 560 & $0.281652 \pm 4$ & -40.1 & -23.1 & -5.5 & $0.282174 \pm 4$ & -21.6 & -22.9 & -9.0 & -5.7 \\
\hline 44 Foyle & Te.H & 8.7 & 1110 & $0.282021 \pm 4$ & -27.0 & -16.0 & -3.4 & $0.282568 \pm 4$ & -7.7 & -15.2 & -1.1 & 0.7 \\
\hline 45 Elorn & Te.H & 10.8 & 1120 & $0.282277 \pm 6$ & -18.0 & -11.2 & -1.8 & $0.282653 \pm 4$ & -4.7 & -10.9 & -1.4 & 0.1 \\
\hline 46 Swilly & Te.H & 8.7 & 1110 & $0.282116 \pm 4$ & -23.7 & -13.3 & -4.3 & $0.282570 \pm 4$ & -7.6 & -13.9 & -2.0 & -0.2 \\
\hline \multicolumn{13}{|c|}{ Rivers draining volcanic rocks } \\
\hline 47 Kamchatka & Cold.D & -2.6 & 580 & not analyzed & & & & $0.283167 \pm 7$ & 13.5 & 7.2 & 2.7 & 6.3 \\
\hline 48 Waikato & Te.H & 11.7 & 1840 & $0.282883 \pm 5$ & 3.5 & 0.5 & 1.5 & $0.282890 \pm 5$ & 3.7 & 0.4 & -1.8 & -1.1 \\
\hline 49 Lower Bann & Te.H & 8.7 & 1000 & $0.282367 \pm 5$ & -14.8 & -8.9 & -2.2 & $0.282781 \pm 12$ & -0.2 & -8.9 & 1.5 & 3.4 \\
\hline 50 Maine & Te.H & 8.7 & 1000 & $0.282832 \pm 7$ & 1.7 & 0.1 & 0.2 & $0.283037 \pm 5$ & 8.9 & 0.6 & 3.2 & 5.1 \\
\hline 51 Six Mile & Te.H & 8.7 & 1000 & $0.282648 \pm 5$ & -4.9 & -2.8 & -1.7 & $0.282963 \pm 5$ & 6.3 & -3.2 & 3.5 & 5.5 \\
\hline 52 Glenariff & Te.H & 8.7 & 1000 & $0.283036 \pm 5$ & 8.9 & 3.7 & 1.9 & $0.283102 \pm 8$ & 11.2 & 3.7 & 3.1 & 5.0 \\
\hline 53 Galets & Tr.W & 24 & 2000 & not analyzed & & & & $0.283029 \pm 6$ & 9.1 & 3.8 & 0.8 & 0.0 \\
\hline
\end{tabular}

Climatic zones: Tr.W (Tropical-wet); Tr.H (Tropical-humid); Te.H (Temperate-humid); Te.D (Temperate-dry); Cold.D (Cold-dry)

${ }^{*}$ All $\varepsilon_{\mathrm{Hf}}$ and $\varepsilon_{\mathrm{Nd}}$ calculated using Bouvier et al. (2008) - CHUR values; $\varepsilon_{\mathrm{Nd}}$ from Bayon et al. (2015)

Res.: Difference between measured and predicted $\Delta \varepsilon_{\mathrm{Hf} \text { clay }}$ values (see text for details) 
Table 3

Average $\Delta \varepsilon_{\mathrm{Hf} \text { clay }}$ and $\mathrm{ClA}$ values for climatic zones

\begin{tabular}{|c|c|c|c|c|c|}
\hline Climatic zones & $\begin{array}{c}\text { MAT } \\
{ }^{\circ} \mathrm{C}\end{array}$ & $\begin{array}{l}\text { MAP } \\
\mathrm{mm}\end{array}$ & $\begin{array}{c}\Delta \varepsilon_{\mathrm{Hf} \text { clay }} \\
( \pm 1 \mathrm{sd})\end{array}$ & $\mathbf{N}$ & $\begin{array}{c}\text { CIA } \\
( \pm 1 \mathrm{sd})\end{array}$ \\
\hline Cold-dry & $<10$ & $<750$ & $-3.0 \pm 2.5$ & 12 & $75 \pm 5$ \\
\hline Temperate-dry & $>10<20$ & $<750$ & $-1.1 \pm 1.2$ & 11 & $80 \pm 6$ \\
\hline Temperate-humid & $>8<20$ & $>1000$ & $-0.6 \pm 0.5$ & 9 & $81 \pm 4$ \\
\hline Tropical-humid & $>20$ & $<1500$ & $1.4 \pm 1.0$ & 4 & $85 \pm 3$ \\
\hline Tropical-wet & $>20$ & $>1500$ & $2.1 \pm 1.3$ & 8 & $89 \pm 6$ \\
\hline
\end{tabular}


Table S1

Geographical location of studied river sediments and clay versus silt weight percents.

\begin{tabular}{|c|c|c|c|c|c|c|c|}
\hline $\begin{array}{l}\text { Sample } \\
\text { River }\end{array}$ & $\begin{array}{c}\text { Area } \\
\left(10^{3} \mathrm{~km}^{2}\right)\end{array}$ & Country & $\begin{array}{c}\text { Sampling } \\
\text { Environment }\end{array}$ & Lat. & Long. & $\begin{array}{l}\text { Silt } \\
\text { wt \% }\end{array}$ & $\begin{array}{l}\text { Clay } \\
\text { wt \% }\end{array}$ \\
\hline \multicolumn{8}{|l|}{ Large rivers } \\
\hline 1 Amazon & 6300 & Brazil & Sub Delta & 3.10 & 43.39 & & \\
\hline 2 Congo & 3800 & DRC & Margin & -5.70 & 11.23 & 56 & 44 \\
\hline 3 Mississipi & 3300 & USA & Sub Delta & 28.93 & 89.49 & 82 & 18 \\
\hline 4 Nile & 2900 & Egypt & Margin & 32.51 & 30.38 & 85 & 15 \\
\hline 5 Niger & 2200 & Nigeria & Sub Delta & 3.20 & 6.68 & 80 & 20 \\
\hline 6 Yangtze & 1800 & China & Estuary & 31.62 & 121.01 & 71 & 29 \\
\hline 7 MacKenzie & 1800 & Canada & Sub Delta & 69.26 & -137.29 & 75 & 25 \\
\hline 8 Volga & 1400 & Russia & Estuary & 45.71 & 47.92 & 97 & 3 \\
\hline 9 Murray & 1100 & Australia & River & -35.41 & 139.23 & 95 & 5 \\
\hline 10 Orinoco & 1100 & Venezuela & River & 7.65 & -66.18 & 99.5 & 0.5 \\
\hline 11 Danube & 820 & Romania & River & 45.06 & 29.62 & & \\
\hline 12 Mekong & 800 & Cambodia & Delta & 10.96 & 105.06 & 79 & 21 \\
\hline 13 Yellow River & 750 & China & Delta & 37.80 & 118.91 & 98 & 2 \\
\hline 14 Amu Darya & 535 & Uzbekistan & River & 42.22 & 60.12 & 98 & 2 \\
\hline 15 Don & 420 & Russia & River & 47.29 & 39.10 & 97 & 3 \\
\hline 16 Northern Dvina & 357 & Russia & Estuary & 65.09 & 39.00 & 82 & 18 \\
\hline 17 Fraser & 230 & Canada & Sub Delta & 49.16 & -123.37 & 90 & 10 \\
\hline 18 Rhine & 220 & Netherlands & Estuary & 51.91 & 4.48 & 97 & 3 \\
\hline 19 Vistula & 200 & Poland & Gulf & 54.65 & 19.28 & 90 & 10 \\
\hline 20 Red River & 160 & Vietnam & Delta & 20.26 & 106.52 & 79 & 21 \\
\hline 21 Chao Phraya & 160 & Thailand & Delta & 13.57 & 100.58 & 78 & 22 \\
\hline 22 Loire & 120 & France & Estuary & 47.28 & -1.90 & 88 & 12 \\
\hline \multicolumn{8}{|c|}{ Rivers draining mixed/sedimentary formations } \\
\hline 23 Seine & 79 & France & Estuary & 49.47 & 0.42 & 97 & 3 \\
\hline 24 Fly & 76 & PNG & Sub Delta & -8.67 & 144.00 & 79 & 21 \\
\hline 25 Guadiana & 67 & Portugal & Estuary & 37.21 & -7.42 & & \\
\hline 26 Chubut & 45 & Argentina & Rlver & -43.25 & -65.20 & 99 & 1 \\
\hline 27 Mae Klong & 31 & Thailand & River & 13.43 & 99.95 & 82 & 18 \\
\hline 28 Shannon & 23 & Eire & Estuary & 52.69 & -8.91 & 96 & 4 \\
\hline 29 Adour & 16 & France & River & 43.49 & -1.47 & 96 & 4 \\
\hline 30 Sefid Rud & 13 & Iran & River & 37.47 & 49.94 & 93 & 7 \\
\hline 31 Mayenne & 4.4 & France & River & 47.50 & -0.55 & 91 & 9 \\
\hline 32 Var & 2.8 & France & River & 43.67 & 7.20 & 98 & 2 \\
\hline 33 Blackwater & 1.1 & Ireland & River & 54.51 & -6.58 & 94 & 6 \\
\hline 34 Moyola & 0.3 & Ireland & River & 54.75 & -6.52 & 97 & 3 \\
\hline \multicolumn{8}{|c|}{ Rivers draining igneous/metamorphic terranes } \\
\hline 35 Rio Caroni & 95 & Venezuela & River & 8.33 & -62.71 & 98 & 2 \\
\hline 36 Narva & 56 & Estonia & Estuary & 59.54 & 27.58 & 96 & 4 \\
\hline 37 Rio Caura & 48 & Venezuela & River & 7.58 & -64.94 & 94 & 6 \\
\hline 38 Kymijoki & 37 & Finland & Estuary & 60.46 & 26.91 & 85 & 15 \\
\hline 39 Rio Aro & 30 & Venezuela & River & 7.39 & -64.01 & 97 & 3 \\
\hline 40 Ume & 26 & Sweden & Estuary & 63.72 & 20.27 & 98 & 2 \\
\hline 41 Lule & 25 & Norway & River & 65.68 & 21.82 & 98 & 2 \\
\hline 42 Tana & 16 & Norway & River & 70.20 & 28.19 & & \\
\hline 43 Kiiminkijoki & 3.8 & Finland & River & 65.13 & 25.73 & 98 & 2 \\
\hline 44 Foyle & 2.9 & Ireland & River & 54.76 & -7.45 & 98 & 2 \\
\hline 45 Elorn & 0.3 & France & Estuary & 48.40 & -4.38 & 96 & 4 \\
\hline 46 Swilly & 0.1 & Ireland & River & 54.93 & -7.81 & 99 & 1 \\
\hline \multicolumn{8}{|c|}{ Rivers draining volcanic rocks } \\
\hline 47 Kamchatka & 56 & Russia & River & & & & \\
\hline 48 Waikato & 14 & $\begin{array}{c}\text { New } \\
\text { Zealand }\end{array}$ & River & -38.49 & 176.29 & 93 & 7 \\
\hline 49 Lower Bann & 5.8 & Ireland & River & 54.86 & -6.48 & 98 & 2 \\
\hline 50 Maine & 0.29 & Ireland & River & 54.75 & -6.32 & 93 & 7 \\
\hline 51 Six Mile & 0.3 & Ireland & Rlver & 54.70 & -6.15 & 88 & 12 \\
\hline 52 Glenariff & $<0.1$ & Ireland & River & 55.02 & -6.11 & 98 & 2 \\
\hline 53 Galets & $<0.1$ & $\begin{array}{l}\text { Reunion } \\
\text { Island }\end{array}$ & River & -20.95 & 55.30 & & \\
\hline
\end{tabular}

* $\mathrm{Zr}$-Hf concentrations and CIA values from Bayon et al. (2015) 
Table S2

Trace element composition (ppm) of World river silts and clays and CIA (clays).

\begin{tabular}{|c|c|c|c|c|c|c|c|c|c|c|c|c|}
\hline \multicolumn{2}{|r|}{ Sample } & \multicolumn{4}{|c|}{ Silts } & \multicolumn{6}{|c|}{ Clays } & \multirow{2}{*}{ CIA } \\
\hline$\#$ & River & $\mathrm{Zr}$ & $\mathrm{Nd}$ & Lu & $\mathrm{Hf}$ & Lu/Hf & $\mathrm{Zr}$ & $\mathrm{Nd}$ & Lu & Hf & Lu/Hf & \\
\hline \multicolumn{13}{|c|}{ Large rivers } \\
\hline & Amazon & 203 & 40.3 & 0.54 & 5.30 & 0.101 & 124 & 48.22 & 0.50 & 3.35 & 0.149 & 87 \\
\hline 2 & Congo & 141 & 46.0 & 0.36 & 4.21 & 0.085 & 129 & 45.4 & 0.34 & 3.47 & 0.097 & 92 \\
\hline & Mississipi & 320 & 30.3 & 0.43 & 8.42 & 0.050 & 135 & 39.8 & 0.44 & 3.65 & 0.119 & 84 \\
\hline & Nile & 518 & 31.6 & 0.48 & 13.1 & 0.036 & 228 & 35.8 & 0.38 & 5.33 & 0.071 & 80 \\
\hline & Niger & 139 & 43.2 & 0.32 & 3.95 & 0.080 & 118 & 43.6 & 0.30 & 2.92 & 0.103 & 86 \\
\hline 6 & Yangtze & 210 & 34.0 & 0.41 & 5.97 & 0.068 & 145 & 35.8 & 0.45 & 3.90 & 0.116 & 78 \\
\hline & MacKenzie & 174 & 31.1 & 0.39 & 4.80 & 0.081 & 150 & 39.8 & 0.47 & 3.88 & 0.121 & 79 \\
\hline 8 & Volga & 706 & 27.9 & 0.47 & 17.6 & 0.027 & 151 & 31.1 & 0.40 & 3.77 & 0.107 & 79 \\
\hline 9 & Murray & 158 & 25.6 & 0.35 & 4.61 & 0.076 & 139 & 25.1 & 0.35 & 3.68 & 0.096 & 86 \\
\hline 10 & Orinoco & 3476 & 42.4 & 1.48 & 82.4 & 0.018 & 377 & 52.1 & 0.66 & 9.25 & 0.071 & - \\
\hline 11 & Danube & \multicolumn{4}{|c|}{ not analyzed } & & 87 & 21.8 & 0.25 & 2.09 & 0.120 & - \\
\hline 12 & Mekong & 363 & 28.7 & 0.43 & 9.20 & 0.047 & 137 & 39.0 & 0.52 & 3.73 & 0.139 & 87 \\
\hline 13 & Yellow River & 398 & 29.0 & 0.41 & 10.2 & 0.041 & 125 & 27.4 & 0.35 & 3.16 & 0.111 & 68 \\
\hline 14 & Amu Darya & 484 & 34.4 & 0.52 & 12.6 & 0.041 & 186 & 23.3 & 0.38 & 5.01 & 0.076 & - \\
\hline 15 & Don & 371 & 18.0 & 0.28 & 8.81 & 0.032 & 139 & 29.2 & 0.35 & 3.61 & 0.097 & 82 \\
\hline 16 & Northern Dvina & 158 & 37.5 & 0.37 & 4.37 & 0.084 & 125 & 39.6 & 0.37 & 3.20 & 0.115 & 70 \\
\hline 17 & Fraser & 171 & 24.3 & 0.32 & 4.59 & 0.070 & 124 & 20.1 & 0.32 & 3.04 & 0.105 & 74 \\
\hline 18 & Rhine & 443 & 27.2 & 0.39 & 11.5 & 0.034 & 96 & 26.1 & 0.31 & 2.36 & 0.132 & 76 \\
\hline 19 & Vistula & 235 & 27.8 & 0.37 & 6.28 & 0.059 & 119 & 32.9 & 0.35 & 3.31 & 0.106 & 74 \\
\hline 20 & Red River & 234 & 37.1 & 0.44 & 6.20 & 0.071 & 183 & 51.1 & 0.59 & 4.74 & 0.124 & 81 \\
\hline 21 & Chao Phraya & 223 & 30.3 & 0.42 & 6.07 & 0.069 & 127 & 37.7 & 0.50 & 3.42 & 0.147 & 86 \\
\hline 22 & Loire & 214 & 39.71 & 0.41 & 5.77 & 0.072 & 114 & 39.0 & 0.34 & 3.04 & 0.113 & 84 \\
\hline \multicolumn{13}{|c|}{ Rivers draining mixed/sedimentary formations } \\
\hline 23 & Seine & 606 & 25.7 & 0.44 & 14.2 & 0.031 & 135 & 33.4 & 0.36 & 3.41 & 0.105 & 79 \\
\hline 24 & Fly & 281 & 32.4 & 0.41 & 7.34 & 0.056 & 184 & 32.7 & 0.46 & 4.88 & 0.093 & 83 \\
\hline 25 & Guadiana & \multicolumn{4}{|c|}{ not analyzed } & & 147 & 34.1 & 0.45 & 3.93 & 0.115 & 84 \\
\hline 26 & Chubut & 613 & 26.8 & 0.48 & 14.8 & 0.032 & 192 & 32.4 & 0.50 & 4.49 & 0.111 & 73 \\
\hline 27 & Mae Klong & 210 & 37.4 & 0.45 & 5.90 & 0.077 & 117 & 43.4 & 0.49 & 3.24 & 0.150 & 86 \\
\hline 28 & Shannon & 841 & 33.0 & 0.64 & 20.0 & 0.032 & 151 & 39.7 & 0.47 & 3.89 & 0.120 & 80 \\
\hline & Adour & 599 & 33.6 & 0.48 & 15.9 & 0.030 & 113 & 38.7 & 0.39 & 2.91 & 0.135 & 83 \\
\hline 30 & Sefid Rud & 229 & 26.2 & 0.35 & 6.00 & 0.058 & 166 & 32.9 & 0.45 & 3.97 & 0.113 & 81 \\
\hline 31 & Mayenne & 354 & 32.6 & 0.46 & 9.12 & 0.051 & 188 & 38.3 & 0.45 & 3.68 & 0.121 & 84 \\
\hline 32 & Var & 233 & 27.1 & 0.31 & 6.44 & 0.048 & 124 & 29.0 & 0.34 & 3.72 & 0.092 & - \\
\hline & Blackwater & 479 & 26.0 & 0.37 & 12.0 & 0.031 & 135 & 43.0 & 0.47 & 3.43 & 0.136 & 87 \\
\hline 34 & Moyola & 566 & 28.6 & 0.39 & 14.5 & 0.027 & 97 & 43.6 & 0.34 & 2.49 & 0.136 & 82 \\
\hline \multicolumn{13}{|c|}{ Rivers draining igneous/metamorphic terranes } \\
\hline 35 & Rio Caroni & 1476 & 31.1 & 0.69 & 34.9 & 0.020 & 207 & 50.7 & 0.44 & 4.94 & 0.089 & 96 \\
\hline & Narva & 302 & 36.9 & 0.48 & 8.03 & 0.059 & 172 & 52.6 & 0.53 & 4.33 & 0.122 & 71 \\
\hline & Rio Caura & 811 & 29.8 & 0.52 & 20.2 & 0.026 & 202 & 54.0 & 0.46 & 4.66 & 0.099 & 96 \\
\hline 38 & Kymijoki & 192 & 44.5 & 0.46 & 5.57 & 0.082 & 109 & 48.4 & 0.44 & 3.05 & 0.143 & 67 \\
\hline & Rio Aro & 920 & 42.6 & 0.46 & 23.7 & 0.020 & 108 & 38.8 & 0.29 & 2.84 & 0.101 & - \\
\hline & Ume & 394 & 41.8 & 0.47 & 10.6 & 0.044 & 131 & 64.1 & 0.49 & 3.71 & 0.133 & - \\
\hline & Lule & 623 & 41.0 & 0.65 & 15.6 & 0.042 & 161 & 43.7 & 0.49 & 4.38 & 0.112 & - \\
\hline & Tana & 231 & 30.8 & 0.33 & 6.16 & 0.053 & 106 & 53.3 & 0.41 & 3.21 & 0.126 & 76 \\
\hline 43 & Kiiminkijoki & 350 & 26.8 & 0.32 & 9.10 & 0.035 & 137 & 38.4 & 0.34 & 3.56 & 0.096 & - \\
\hline 44 & Foyle & 715 & 38.6 & 0.52 & 18.3 & 0.028 & 100 & 59.6 & 0.45 & 2.56 & 0.174 & 79 \\
\hline & Elorn & 452 & 39.3 & 0.51 & 12.0 & 0.043 & 107 & 35.4 & 0.36 & 3.17 & 0.114 & 83 \\
\hline 46 & Swilly & 1024 & 49.7 & 0.84 & 25.8 & 0.032 & 171 & 77.9 & 0.70 & 4.33 & 0.162 & \\
\hline \multicolumn{13}{|c|}{ Rivers draining volcanic rocks } \\
\hline & Kamchatka & \multicolumn{4}{|c|}{ not analyzed } & & 81 & 7.6 & 0.15 & 2.04 & 0.073 & 52 \\
\hline 48 & Waikato & 217 & 23.6 & 0.48 & 5.89 & 0.081 & 156 & 26.9 & 0.52 & 4.01 & 0.131 & 76 \\
\hline 49 & Lower Bann & 286 & 20.6 & 0.44 & 7.49 & 0.058 & 134 & 26.3 & 0.44 & 3.33 & 0.132 & 88 \\
\hline 50 & Maine & 154 & 14.8 & 0.41 & 4.09 & 0.101 & 107 & 16.4 & 0.49 & 2.68 & 0.185 & 93 \\
\hline 51 & Six Mile & 188 & 15.9 & 0.39 & 4.99 & 0.078 & 93 & 15.6 & 0.41 & 2.54 & 0.161 & 91 \\
\hline & Glenariff & 193 & 15.8 & 0.46 & 5.19 & 0.089 & 134 & 15.6 & 0.44 & 3.13 & 0.142 & 95 \\
\hline & Galets & 190 & 18.8 & 0.22 & 4.94 & 0.046 & 193 & 15.4 & 0.16 & 4.29 & 0.038 & - \\
\hline
\end{tabular}

